\title{
1 Investigating the metal contamination of sediment transported by the 2016 Seine River flood (Paris, France)
}

3 Marion Le Galla $^{\text {, Sophie Ayraulta }}$, Olivier Evrarda ${ }^{a}$, J. Patrick Laceby ${ }^{b}$, D. Gateuille ${ }^{c}$, Irène Lefèvre ${ }^{a}$,

4 Jean-Marie Moucheld, Michel Meybeck ${ }^{d}$

5 a Laboratoire des Sciences du Climat et de l'Environnement, UMR 8212 (CEA/CNRS/UVSQ), Université Paris-Saclay,

6 Domaine du CNRS, Avenue de la Terrasse, 91198 Gif-sur-Yvette Cedex, France

$7 \quad{ }^{b}$ Environmental Monitoring and Science Division, Alberta Environment and Parks, 3115-12 Street NE

8 Calgary, Alberta, Canada

9 c Laboratoire de Chimie Moléculaire et Environnement, Université Savoie Mont-Blanc, 73376 Le Bourget du Lac Cedex, 10 France

$11{ }^{a}$ Milieux Environnementaux, Transferts et Interactions dans les hydrosystèmes et les Sols (UPMC/CNRS/EPHE), UMR

12 7619, Université Pierre et Marie Curie, 4 place de Jussieu, Paris Cedex, France 


\section{Abstract}

33 Fine sediment transport in rivers is exacerbated during flood events. These particles may convey 34 various contaminants (i.e. metals, pathogens, industrial chemicals, etc.), and significantly impact 35 water quality. The exceptional June 2016 flood of the Seine River (catchment area: $65000 \mathrm{~km}^{2}$, 36 France), potentially mobilized and deposited contaminated materials throughout the Paris region. 37 Flood sediment deposits $(n=29)$ were collected along the Seine River and its main tributaries 38 upstream (Yonne, Loing and Marne Rivers) and downstream of Paris (Oise and Eure Rivers). 39 Fallout radionuclides $\left({ }^{137} \mathrm{Cs},{ }^{7} \mathrm{Be}\right)$ were measured to characterize the sources of the material 40 transiting the river, while trace elements (e.g. $\mathrm{Cr}, \mathrm{Ni}, \mathrm{Zn}, \mathrm{Cu}, \mathrm{As}, \mathrm{Cd}, \mathrm{Sb}, \mathrm{Pb}, \mathrm{Tl}, \mathrm{Ag}$ ) and stable 41 lead isotopes $\left({ }^{206} \mathrm{~Pb} /{ }^{207} \mathrm{~Pb}\right)$ were analyzed to quantify the contamination of sediment transported 42 during the flood. In upper sections of the Seine River, sediment mainly originated from the 43 remobilization of particles with a well-balanced contribution of surface and subsurface sources. In 44 the upstream tributaries, sediment almost exclusively originated from the remobilization of 45 subsurface particles. In Paris and downstream of Paris, recently eroded particles and surface 46 sources dominated the sediment, suggesting particles were mainly supplied by urban runoff and 47 the erosion of agricultural soils. The highest metal concentrations and enrichment factors (EF) 48 were found in the sediment collected in the Loing, Orge and Yvette upstream tributaries. Although 49 these inputs were diluted in the Seine River, an increase in elemental concentrations was 50 observed, progressing downstream through Paris. However, EFs in sediment collected along the 51 Seine River were lower or in the same range of values sampled over the last several decades, 52 reflecting the progressive decontamination of the urbanized Seine River basin.

\section{Capsule}

55 During the June 2016 flood of the Seine River there was a flush of contaminated sediment 56 originating from upstream tributaries, while along the Seine River, sediment metal concentrations 57 remained lower than historical records.

59 Keywords: Fallout radionuclides, trace elements, lead isotopes, fingerprinting 
62 Trace elements are naturally found in the environment, although at low background levels, as they

63 are released by natural processes such as bedrock weathering or volcanic eruptions. However, 64 anthropogenic activities may supply excessive quantities of metals and metalloids to the 65 environment (Elbaz-Poulichet et al., 2001; Coynel et al., 2009; Resongles et al., 2014). In 66 particular, large amounts of metals and metal compounds are released by industrial, domestic and 67 agricultural activities (Suthar et al., 2009; Le Pape et al., 2012; Rosolen et al., 2015). In urbanized 68 catchments, atmospheric fallout associated with anthropogenic activities provides one of the main 69 pathways of soil contamination (Nriagu, 1989; Pacyna and Pacyna, 2001). Once emitted into the 70 atmosphere, trace elements are transported and deposited through wet and dry fallout on soils 71 where they may accumulate and be stored over long periods (Bindler et al., 2009; Bur et al., 2009). 72 These hazardous compounds may be preferentially bound to fine particles (i.e. <63 $\mu \mathrm{m}$ ) (Blake et 73 al., 2003; Owens et al., 2005) and they may subsequently be delivered to the riverine environment 74 by processes such as soil leaching or soil erosion (Nystrand et al., 2012; Mileusnić et al., 2014; 75 Zheng et al., 2016). The temporal dynamics of contaminants released by erosion processes are not well understood in urbanized catchments characterized by extensive impervious surfaces. Although sediment and associated metals may accumulate in the river channel during low flow periods, they are mainly re-suspended and transported during flood events. Therefore, significant amounts of metals may be exported by rivers during very short periods (Cobelo-Garcia et al., 2004; Carter et al., 2006; Ollivier et al., 2011). Accordingly, the monitoring of flood events with high-temporal resolution sampling is essential to better understand trace element dynamics at the catchment scale (Cánovas et al., 2008). Studies based on robust flood monitoring remain scarce and, to the best of our knowledge, they were mainly restricted to small catchments impacted by former mining activities (Coynel et al., 2007; Turner et al., 2008; Resongles et al., 2015). The sampling of lag deposits may constitute an effective strategy to overcome the lack of sediment monitoring during extreme events (Lepage et al., 2016). Representative of the fine material transported by the flood and deposited during the falling limb (Olley et al., 2012), lag deposits are similar to fresh floodplain deposits originating from various catchment sources (Du Laing et al., 2009). Currently, there is a lack of data regarding the impact of flood events on water and sediment quality in large urbanized catchments (Baborowski and Einax, 2016). Furthermore, the determination of metal contents together with the identification and quantification of sediment

92 sources during flood events are necessary for understanding their transfer at the catchment scale.

93 Indeed, identifying both spatial and temporal sources of sediment is essential to interpret sediment 
94 contamination levels and evaluate the resilience of major urbanized catchments. This important 95 distinction may be resolved by combining several sediment source tracers (Bradley and Cox, 96 1990; Krüger et al., 2005).

97 Sediment sources may be identified by combining ${ }^{137} \mathrm{Cs}$ and ${ }^{7} \mathrm{Be}$ measurements. ${ }^{137} \mathrm{Cs}\left(\mathrm{t}_{1 / 2}=30\right.$ years) is an artificial radionuclide originating from thermonuclear tests (1950-1960s) and the Chernobyl accident in Northwestern Europe. Predominantly fixed to fine particles, ${ }^{137} \mathrm{Cs}$ discriminates between material eroded from the soil surface, exposed to atmospheric fallout, and from subsurface soils, sheltered from ${ }^{137} \mathrm{Cs}$ fallout (He and Walling, 1997; Motha et al., 2003). ${ }^{7} \mathrm{Be}$ $\left(t_{1 / 2}=53\right.$ days $)$ is a short-lived cosmogenic radionuclide, supplied to the soil surface by precipitation, that discriminates between recently eroded particles, tagged with ${ }^{7} \mathrm{Be}$ and older resuspended particles, depleted in ${ }^{7} \mathrm{Be}$ (Dominik et al., 1987; Taylor et al., 2013). Using these radionuclides, the relative contribution of four different sources (i.e. recently eroded surface and subsurface, re-suspended surface and subsurface) to sediment may be quantified and interpreted in terms of contamination levels using elemental concentrations (Evrard et al., 2016).

In this study, sediment sources and metal contamination levels were investigated during an exceptional flood event that occurred in June 2016 in the Seine River basin, France, representative of the industrialized areas of Northwestern Europe. This catchment, with approximately 16 million inhabitants, drains the Megacity of Paris and concentrates more than a third of the French heavy industries, leading to the coexistence of major anthropogenic pollution sources, including metal contamination (Meybeck et al., 2004; Grosbois et al., 2006; Thévenot et al., 2009). Although the June 2016 flood mainly affected the upstream tributaries with a return period > 50 years for the Loing tributary, the flood propagated along the Seine River with return periods estimated to be 10-20 years in Paris and 2-5 years in its downstream section near Poses. This flood was unprecedented, with the largest inundation in the Paris city center since the extreme flood event in 1910. In this context, stakeholder concerns arose regarding water quality, especially metal contamination. Furthermore, in the framework of the candidacy of Paris to host the 2024 Summer Olympics, the Seine River should be of sufficient water quality to hold the nautical competitions. The potential environmental impact of such major flood events needs to be investigated. Sediment metal contamination levels reached during this major flood need to be compared to historical data, and the sources of this contamination need to be investigated (i.e. contribution of recently eroded particle from impervious urban areas vs remobilized particles deposited on the riverbed during the last several decades). Accordingly, ${ }^{137} \mathrm{Cs}$ and ${ }^{7} \mathrm{Be}$ 
$127 \mathrm{Sb}, \mathrm{Pb}, \mathrm{Ag}, \mathrm{Tl})$ and stable lead isotopes $\left({ }^{207} \mathrm{~Pb} /{ }^{206} \mathrm{~Pb}\right)$ in lag deposits collected in the catchment to 128 investigate the urban sediment contamination and the spatial and temporal variations of their 129 sources during the June 2016 flood event in the Seine River basin, France. In addition, Predicted 130 No Effect Concentrations (PNEC) were used to examine the potential toxicity of these 131 contaminants on the environment.

\section{Material and methods}

\subsection{Study area}

135 The Seine River basin $\left(65000 \mathrm{~km}^{2}\right)$ is located in Northern France and is characterized by 136 homogeneous relief, geology and climate properties. The underlying bedrock is mainly 137 sedimentary ( 93\%) with the predominance of carbonate rocks (chalk, limestone) while silicate 138 rocks (7\%) are restricted to the upstream Morvan area. Five main tributaries drain into the Seine 139 River: the Aube $\left(4750 \mathrm{~km}^{2}\right)$, the Yonne $\left(11250 \mathrm{~km}^{2}\right)$ and the Marne Rivers $\left(13160 \mathrm{~km}^{2}\right)$ flow into 140 the Seine upstream of Paris, whereas the Oise $\left(16900 \mathrm{~km}^{2}\right)$ and the Eure Rivers $\left(6017 \mathrm{~km}^{2}\right)$ flow 141 into the Seine downstream of Paris (Meybeck, 1998).

142 The land use is heterogeneous, with $25 \%$ of the catchment area dedicated to agricultural 143 production and $40 \%$ to industrial activities. Agriculture is predominant upstream of Paris, whereas 144 industrial activities are located near and downstream of Paris. With a mean population density of 145250 inhabitants $\mathrm{km}^{-2}$, varying from 15 inhabitants $\mathrm{km}^{-2}$ in rural areas to a maximal value of 27000 146 inhabitants $\mathrm{km}^{-2}$ in the Paris conurbation, $23 \%$ of the French population lives in the Seine River 147 catchment, which only covers $12 \%$ of the French surface area. The variations in land use, 148 industrial activities and population density lead to variable anthropogenic pressures.

149 To investigate the spatial and temporal variations of metal contamination in sediment transported 150 during the May 26 to June 4, 2016 flood event, attention focused on the flood sediment deposits 151 collected along the Seine River $(n=16)$ (from Bray-sur-Seine, upstream of the Yonne confluence, 152 to Poses, the river mouth, $200 \mathrm{~km}$ downstream of Paris). Sediment deposits were also collected 153 along the main tributaries $(n=13)$, just before their junction with the Seine River: the Yonne, the 154 Loing, the Orge, the Yvette and the Marne Rivers upstream of Paris and the Oise and the Eure 155 Rivers downstream of Paris (Figure 1). 


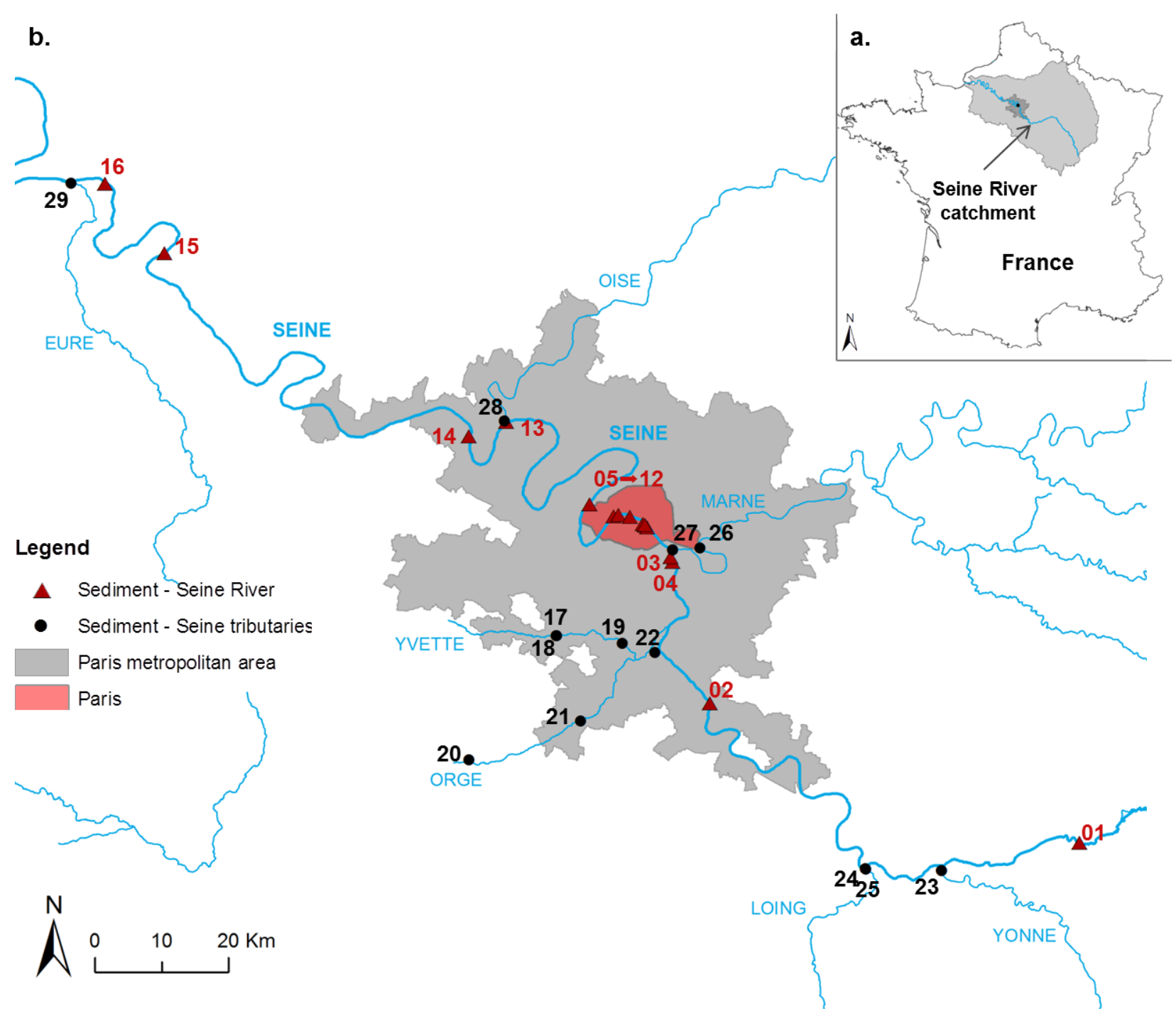

Figure 1. Map of the Seine River basin (France) (a) with the detailed map of the study area (b) and the location of the sediment samples collected along the Seine River (red) and its tributaries (in black).

\subsection{Flood characteristics}

162 From May 26 to June 4, 2016, a stationary low pressure system over France induced moderate 163 although continuous rainfall during three days, from May 29 to May 31. This precipitation followed 164 a particularly wet spring season. Soils were saturated and the additional rainfall first generated 165 overflow of small rivers such as the Loing and Yvette. The upstream Loing tributary quickly reacted to heavy rainfall and several towns were flooded on June 1, with more than 4000 people evacuated in the city of Nemours. Although this catchment only covers $9 \%$ of the Seine River basin surface area, the Loing River contributed to $25 \%$ of the flood peak of the Seine River. The Yvette River, a small although highly urbanized tributary, also flooded several towns on June 2, with 2000 people evacuated in the town of Longjumeau. Characterized by return periods $>50$ years, the flood of 
171 these upstream tributaries propagated along the Seine River that reached its highest level on June 1723 with a return period estimated to 10-20 years in Paris. However, flood impacts in Paris were less 173 significant than in upper catchment areas and facilities vulnerable to flooding remained mainly 174 unaffected (Van Oldenborgh et al., 2016).

\subsection{Sampling and processing}

176 Lag deposit sediment samples were collected following the flood of the Seine River. They were 177 collected with a Teflon spatula to avoid any metallic contamination and oven-dried ( $\sim 8 \mathrm{~h}$ ) prior to 178 analyses. Sediment samples were sieved to $2 \mathrm{~mm}$ for gamma spectrometry analyses and sieved 179 to $63 \mu \mathrm{m}$ for geochemical analyses.

\subsection{Analyses}

\subsubsection{Radionuclide analyses}

182 Fallout radionuclide activities $\left({ }^{137} \mathrm{Cs},{ }^{7} \mathrm{Be}\right.$ in $\left.\mathrm{Bq} \mathrm{kg}^{-1}\right)$ were measured by gamma spectrometry at 183 the Laboratoire des Sciences du Climat et de l'Environnement (Gif-sur-Yvette, France) following 184 methods detailed by Gateuille et al. (2014). Between 50 and $80 \mathrm{~g}$ of sediment was analyzed, and 185 measured activities were decay-corrected to the sampling date. Th concentrations ( $\left.\mathrm{mg} \mathrm{kg}^{-1}\right)$ were 186 estimated from ${ }^{228}$ Th activities.

\subsubsection{Geochemical analyses}

188 Geochemical measurements were performed on mineralized sediment samples. Approximately $189100 \mathrm{mg}$ of sediment was successively dissolved by the addition of $\mathrm{HF}(4 \mathrm{~mL}, 47-51 \%), \mathrm{HClO}_{4}(2$ $190 \mathrm{~mL}, 65-71 \%), \mathrm{HCl}(3.75 \mathrm{~mL}, 34-37 \%)$ and $\mathrm{HNO}_{3}(67 \%, 1.25 \mathrm{~mL})$ in closed Teflon vessel on hot191 plates (Digiprep, SCP Science). Samples were cooled and evaporated to dryness between 192 successive steps. Ultrapure reagents were used, a reference material (IAEA lake sediment SL1) 193 and a chemical blank were digested in the same way as the sediment samples to control the 194 mineralization efficiency and evaluate the potential contamination during digestion and analysis.

195 Elemental concentration and lead isotope measurements were performed in mineralized solutions 196 using inductively coupled plasma mass spectrometry (ICP-MS, X Series, CCT II+ Thermoelectron, 197 France). More details are provided in Le Gall et al. (2016) and Ayrault et al. (2012).

\subsection{Modelling approach}

199 The contribution of four distinct end-members was estimated in each sediment sample: re200 suspended surface, re-suspended subsurface, recently eroded surface and recently eroded 
201 subsurface. This approach incorporated both spatial and temporal sediment sources. To this end, 202 surface sources were considered to be enriched in ${ }^{137} \mathrm{Cs}$ compared to subsurface sources, and 203 recently eroded particles were considered to be labelled with ${ }^{7} \mathrm{Be}$ while re-suspended particles 204 were depleted in ${ }^{7} \mathrm{Be}$ (Evrard et al., 2016).

205 A mixing model was used to determine the relative contribution of four distinct end-members to 206 the flood sediment through simultaneously minimizing mixing model difference (MMD) using the 207 solver function in Microsoft Excel:

$$
M M D=\sum_{i=1}^{n}\left(A B S\left(\mathrm{C}_{i}-\left(\sum_{s=1}^{m} \mathrm{P}_{S} \mathrm{~S}_{\mathrm{si}}\right)\right) / \mathrm{C}_{i}\right)
$$

208 where $n$ is the number of fallout radionuclides included in the model (i.e. 2); $C_{i}$ is the activity of 209 fallout radionuclide in sediment sample (i); $m$ is the number of sources in the catchment (i.e. 4); $210 P_{s}$ is the source (s) contribution to sediment; and $S_{s i}$ is the mean fallout radionuclide activity $(i)$ in 211 source $(s)$. The proportional contribution from each source $\left(P_{s}\right)$ was solved using the Solver 212 function in Microsoft Excel with non-negative constraints and the contribution all of the sources 213 summing to 1 . Model uncertainty was summarized by adding and subtracting the analytical 214 uncertainty to sediment samples and rerunning the models and then using the mean difference 215 between the "+" and "-" uncertainty model runs to generalize model uncertainty.

216 The re-suspended surface $(n=64)$ and subsurface $(n=8)$ sources were respectively defined using 217 soil (surface) and channel bank (subsurface) samples collected in upper parts of the Seine River 218 catchment (Gateuille, 2013). The re-suspended surface end-member is enriched in ${ }^{137} \mathrm{Cs}$ 219 compared to the re-suspended subsurface end-member and they are both depleted in ${ }^{7} \mathrm{Be}$. The 220 recently eroded surface end-member was characterized using overland flow samples $(n=6)$ 221 collected in a nearby cultivated catchment (see Le Gall et al. (2017) for more details). This end222 member is defined by enriched ${ }^{7} \mathrm{Be}$ and ${ }^{137} \mathrm{Cs}$ activities. Finally, the recently eroded subsurface 223 end-member was defined using urban runoff samples $(n=3)$ collected in the Orge River, a 224 subcatchment of the Seine River catchment, and is characterized by an enrichment in ${ }^{7} \mathrm{Be}$ and a 225 depletion in ${ }^{137} \mathrm{Cs}$ activities (Froger et al., 2017). As particle size differences may prevent a direct 226 comparison between potential sources and sediment (Laceby et al., 2017), a correcting factor 227 based on thorium concentrations was used.

228 This particle size correction was shown to provide similar or even better results than a classical 229 correction based on Specific Surface Area (SSA) (Foucher et al., 2015). Furthermore, as thorium 
230 is measured by gamma spectrometry, no additional measurement is required. For these reasons,

231 a thorium correcting factor was applied following the equation developed in Le Gall et al. (2016).

\subsection{Statistical tests and Enrichments Factor (EF)}

233 To investigate the correlation between the sediment elemental concentrations and ${ }^{206} \mathrm{~Pb} /{ }^{207} \mathrm{~Pb}$ 234 ratios, statistical tests were performed using XLSTAT: 1) Spearman correlation coefficients were 235 calculated for Th and major elemental concentrations and for the entire dataset normalized to Th 236 and 2) a Principal Component Analysis (PCA) was conducted on the sediment dataset normalized 237 to Th.

238 Enrichment Factors (EF), commonly used to evaluate the anthropogenic supply of an element in 239 a given environment (Szuszkiewicz et al., 2016), were calculated as follows:

$$
E F=\frac{(M e / T h)_{\text {sample }}}{(M e / T h)_{\text {reference }}}
$$

240 where $(\mathrm{Me} / \mathrm{Th})_{\text {sample }}$ is the concentration ratio of the metal $(\mathrm{Cr}, \mathrm{Ni}, \mathrm{Zn}, \mathrm{Cu}, \mathrm{As}, \mathrm{Cd}, \mathrm{Sb}, \mathrm{Pb})$ to $\mathrm{Th}$ in

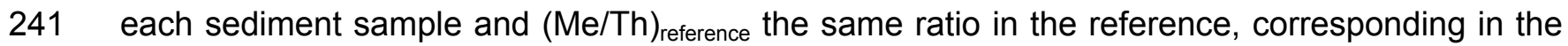
242 current research to the geochemical background of the Seine River (Thévenot et al., 2007; Le 243 Cloarec et al., 2011). This geochemical background was defined using fine sediment $(<100 \mu \mathrm{m})$ 244 at the Seine River mouth combining all the catchment lithologies. As Th is a conservative element 245 that was shown to correct for the particle size effect in similar environments (Foucher et al., 2015), 246 this element was preferred to using Al for EF calculations in this region.

\section{Results}

\subsection{Radionuclide activities in sources and sediment samples}

$250{ }^{137} \mathrm{Cs}$ and ${ }^{7} \mathrm{Be}$ measurements were combined to discriminate and model the contributions of four 251 sources to the flood deposits: re-suspended surface, re-suspended subsurface, recently eroded 252 surface and recently eroded subsurface (Figure 2, Table S1). For the re-suspended surface 253 samples, ${ }^{137} \mathrm{Cs}$ activities ranged between $1.6 \pm 0.2 \mathrm{~Bq} \mathrm{~kg}^{-1}$ and $53.1 \pm 0.7 \mathrm{~Bq} \mathrm{~kg}^{-1}$ (mean $8.0 \mathrm{~Bq}$ $254 \mathrm{~kg}^{-1}$, standard deviation (SD) $0.1 \mathrm{~Bq} \mathrm{~kg}^{-1}$ ) and between $0.0 \pm 0.2$ to $1.6 \pm 0.2 \mathrm{~Bq} \mathrm{~kg}^{-1}$ (mean $0.4 \mathrm{~Bq}$ $255 \mathrm{~kg}^{-1}$, SD $0.3 \mathrm{~Bq} \mathrm{~kg}^{-1}$ ) for re-suspended subsurface samples.

256 The recently eroded surface samples (i.e overland flow samples collected in a cultivated 257 catchment) were characterized by ${ }^{137} \mathrm{Cs}$ activities varying from $3.1 \pm 0.2$ to $16.2 \pm 0.6 \mathrm{~Bq} \mathrm{~kg}^{-1}$ 
258 (mean 4.7 Bq kg-1, SD 4.7 $\mathrm{Bq} \mathrm{kg}^{-1}$ ) and the recently eroded subsurface samples (i.e urban runoff 259 samples) by ${ }^{137} \mathrm{Cs}$ activities varying from $0.0 \pm 0.3$ to $1.2 \pm 0.4 \mathrm{~Bq} \mathrm{~kg}^{-1}$ (mean $0.6 \mathrm{~Bq} \mathrm{~kg}^{-1}, \mathrm{SD}_{0} 0.6$ $\left.260 \mathrm{~Bq} \mathrm{~kg}^{-1}\right)$.

261 Flood sediment was characterized by ${ }^{137} \mathrm{Cs}$ activities varying from $0.0 \pm 1$ to $5.5 \pm 0.4 \mathrm{~Bq} \mathrm{~kg}^{-1}$. The 262 Th normalization was only applied to the re-suspended surface and subsurface end-members (i.e. 263 soil and channel bank samples). Indeed, the other two end-members were defined by fine particle 264 samples (i.e overland flow and urban runoff samples) and did not require a particle size correction 265 as they were sediments and not soils. After normalization, activities in surface soil samples ranged 266 between $3.6 \pm 0.2$ and $10.5 \pm 0.2 \mathrm{~Bq} \mathrm{~kg}^{-1}$ and between $0.0 \pm 0.5$ and $0.7 \pm 0.1 \mathrm{~Bq} \mathrm{~kg}^{-1}$ for channel 267 bank samples, falling well within the range of ${ }^{137} \mathrm{Cs}$ values measured in sediment allowing a direct 268 comparison with these samples.

$269{ }^{7} \mathrm{Be}$ activities in re-suspended sediment sources ranged between $0.0 \pm 2.1$ and $78.4 \pm 25.3 \mathrm{~Bq}$ $270 \mathrm{~kg}^{-1}$ (mean 4.2 $\mathrm{Bq} \mathrm{kg}^{-1}$, SD $17.1 \mathrm{~Bq} \mathrm{~kg}^{-1}$ ) for soil samples and were null for channel bank samples. 271 Recently eroded sources were characterized by ${ }^{7} \mathrm{Be}$ activities ranging between $98.6 \pm 4.5 \mathrm{~Bq} \mathrm{~kg}^{-}$ $272{ }^{1}$ and $418.7 \pm 10.1 \mathrm{~Bq} \mathrm{~kg}^{-1}$ (mean $232.1 \mathrm{~Bq} \mathrm{~kg}^{-1}$, SD $145.6 \mathrm{~Bq} \mathrm{~kg}^{-1}$ ) for overland flow samples and 273 between $102.5 \pm 7.4$ and $412.3 \pm 29.8 \mathrm{~Bq} \mathrm{~kg}^{-1}$ (mean $279.1 \mathrm{~Bq} \mathrm{~kg}^{-1}$, SD $159.4 \mathrm{~Bq} \mathrm{~kg}^{-1}$ ) for urban 274 runoff samples. For sediment samples, ${ }^{7}$ Be activities ranged between $0.0 \pm 9.6 \mathrm{~Bq} \mathrm{~kg}^{-1}$ and 228.5 $275 \pm 6.0 \mathrm{~Bq} \mathrm{~kg}^{-1}$ and were in the range of variations of the sediment sources.

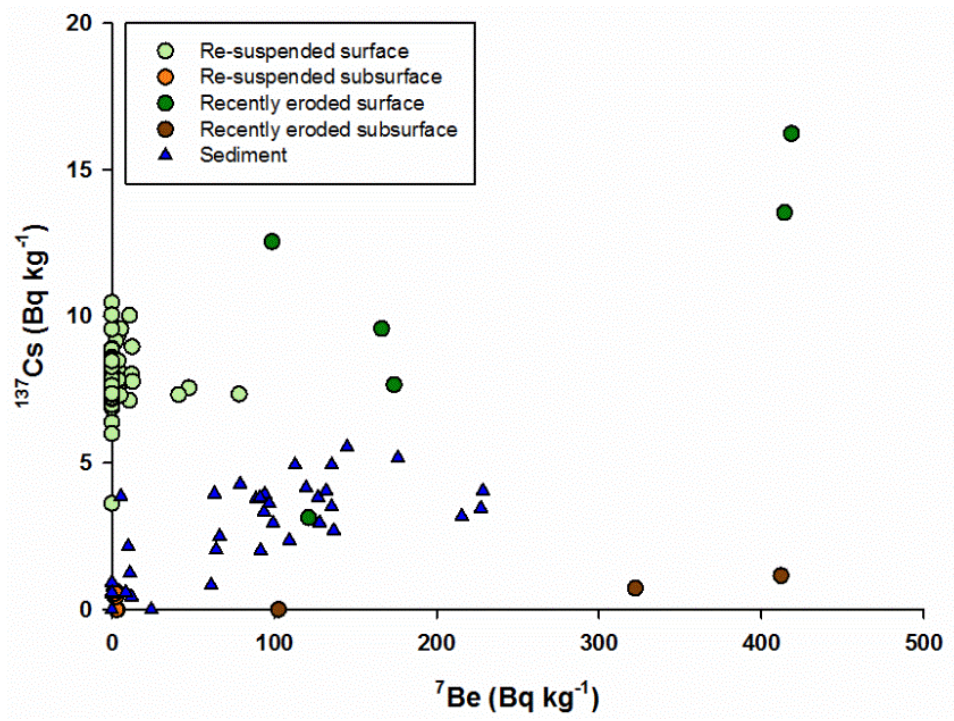

Figure 2. ${ }^{137} \mathrm{Cs}$ and ${ }^{7} \mathrm{Be}$ activities $\left(\mathrm{Bq} \mathrm{kg}{ }^{-1}\right)$ in the four source end-members (i.e re-suspended surface, re278 suspended subsurface, recently eroded surface, recently eroded subsurface) and in sediment. 


\subsection{Modelling results}

280 High variations were observed in the contribution of the four end-members to the sediment (Figure

2813 , Table S2). Upstream of Paris, subsurface sources largely dominated with contributions ranging 282 between $50 \%\left(\mathrm{~N}^{\circ} 25\right)$ and $100 \%$ (22) with the exception of one sediment sample close to Paris 283 (04) with a dominant surface contribution (88\%) (Figure 3a, b). A mixing between recently eroded 284 and re-suspended subsurface sediment was observed for the Yonne (23) and Loing (25) 285 tributaries as for the Seine sediment samples $(01,02)$. Recently eroded subsurface contributions 286 ranged between $17 \%$ and $32 \%$ and re-suspended subsurface contributions between $22 \%$ and $28741 \%$. In the Orge catchment, re-suspended subsurface contributions were the highest, with a 288 mean contribution of $93 \pm 8 \%$ for the Orge and Yvette sediment (17-22). For the Marne tributary, 289 the contribution of the subsurface source dominated with a mean value of $70 \pm 13 \%$. The 290 uppermost Marne sediment sample (26) is characterized by a re-suspended particle contribution 291 of $79 \%$ while for the sediment sampled just before the confluence between the Marne and the 292 Seine Rivers (27), contributions of recently eroded and re-suspended particles as well as surface 293 and subsurface particles were well-balanced, with respective contributions of $48 \%$ and $52 \%$ and 294 of $40 \%$ and $60 \%$. Overall, for the entire set of sediment collected upstream of Paris, subsurface 295 material dominated although a very limited supply of recently eroded surface particles was 296 observed, with contributions ranging between $0 \%$ and $19 \%$ with the exception of one sediment 297 sample (04) with a contribution reaching $47 \%$.

298 In Paris, sediment was dominated by the contribution of surface sources (mean value of $68 \pm$ $29917 \%$ ), especially recently eroded particles with a mean contribution of $48 \pm 14 \%$. The re300 suspended subsurface material contributed between $0 \%$ and $58 \%$ and the recently eroded 301 subsurface contributions were the lowest with proportions between $1 \%$ and $13 \%$ (Figure $3 b$ ).

302 Downstream of Paris, only two sediment samples, collected in Conflans-St-Honorine (13) and 303 Bouafle (15) exhibited high subsurface contributions (71\% and $77 \%$, respectively). In all other 304 samples, recently eroded particles largely dominated with contributions varying between $74 \%$ and $30596 \%$ corresponding to a clear dominance of surface particles with contributions between $51 \%$ and $30684 \%$. Sediment from the Eure (29) and Oise (28) tributaries exhibited the highest recently eroded 307 surface contributions with respective values of $64 \%$ and $84 \%$.

308 
a.

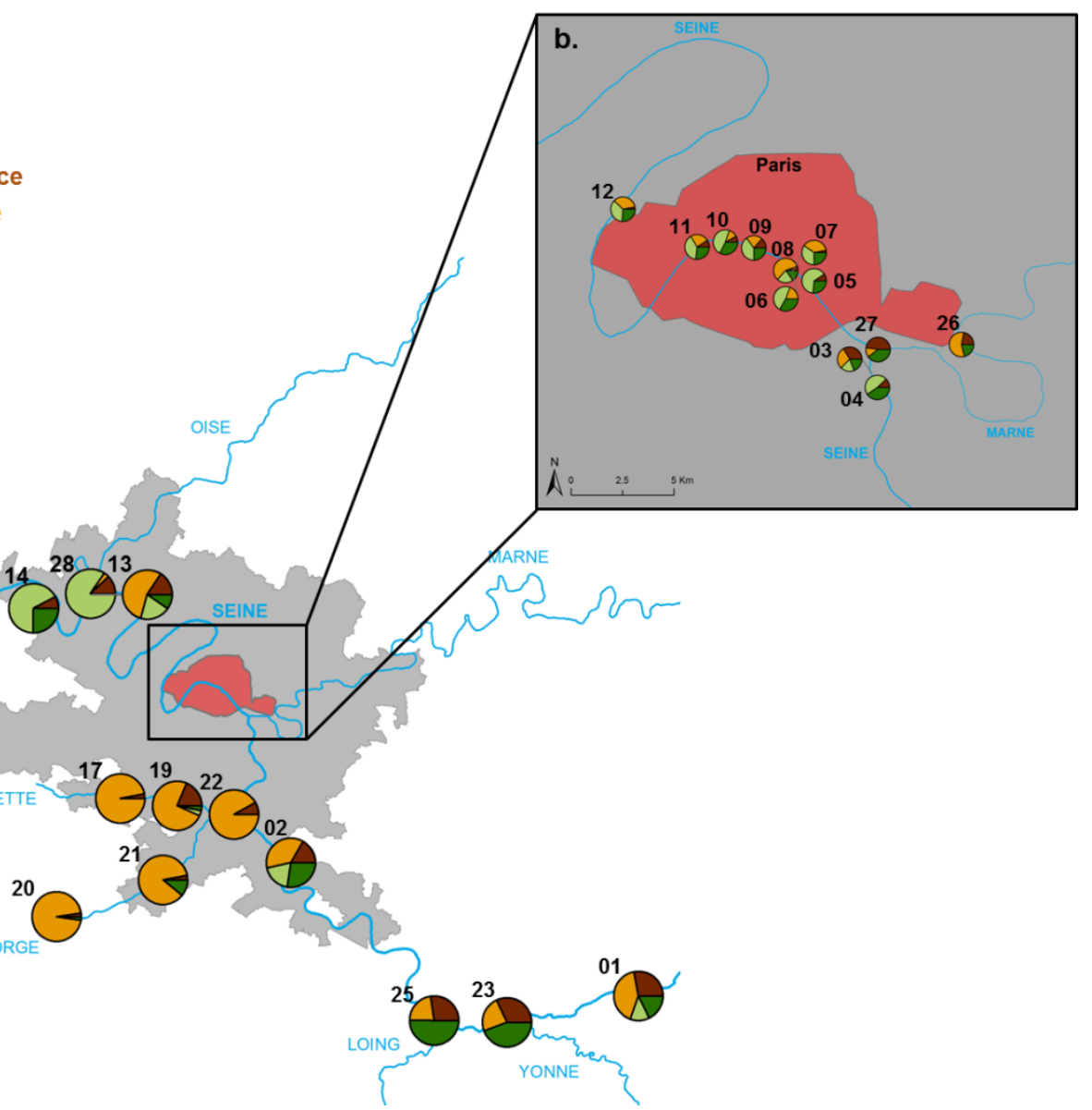

Figure 3. Spatial evolution of the contributions of the four end-members to the sediment collected along the Seine River and its tributaries.

\subsection{Elemental concentrations, lead isotopes in sediment samples}

315 When considering the entire set of sediment samples collected along the Seine River, a global increase in metal and metalloid concentrations was observed in a downstream direction (Figure $\mathrm{kg}^{-1}$ for $\mathrm{Cr}, 15$ and $34 \mathrm{mg} \mathrm{kg}^{-1}$ for Ni, 69 and $402 \mathrm{mg} \mathrm{kg}^{-1}$ for Zn, 14 and $90 \mathrm{mg} \mathrm{kg}^{-1}$ for Cu, 3.2 and $11.3 \mathrm{mg} \mathrm{kg}^{-1}$ for As, 0.3 and $1.9 \mathrm{mg} \mathrm{kg}^{-1}$ for $\mathrm{Cd}, 0.4$ and $3.2 \mathrm{mg} \mathrm{kg}^{-1}$ for Sb, 15 and $214 \mathrm{mg} \mathrm{kg}^{-1}$ for systematically observed in the uppermost Seine River sample (01), with the exception of one sample in Paris (08), showing a slightly lower Ni content. An increase in As and TI concentrations, with respective values of 7.4 to $12.7 \mathrm{mg} \mathrm{kg}^{-1}$ and 0.46 to $0.87 \mathrm{mg} \mathrm{kg}^{-1}$, was observed in sediment collected in Paris compared to the material sampled at both upstream and downstream locations. 
326 collected in Paris (05-12), before decreasing in a downstream direction (13, 14). An increase in 327 Ag content (maximal value of $3.95 \mathrm{mg} \mathrm{kg}^{-1}$ ) was observed just downstream of Paris, and a 328 continuous increase in Cd was observed all along the Seine River sediment. Importantly, sediment 329 collected in Bouafle (15), downstream of the Seine River, was enriched in $\mathrm{Cr}, \mathrm{Ni}, \mathrm{Zn}, \mathrm{Cu}, \mathrm{Cd}, \mathrm{Pb}$ 330 with the highest concentrations measured in the current research.

331 The Yonne River sediment (23) exhibited much higher As (10.8 mg kg-1) and TI (0.89 mg kg-1) 332 concentrations than the Seine River sediment collected before/after the confluence $(01,02,03)$.

333 Sediment from the Loing River $(24,25)$ was particularly enriched in $\mathrm{Zn}\left(165-300 \mathrm{mg} \mathrm{kg}^{-1}\right), \mathrm{Cu}(42-$ $\left.33467 \mathrm{mg} \mathrm{kg}^{-1}\right)$, As (10.2-11.3 mg kg-1), Cd (0.8-1.1 mg kg-1), Sb (1.6-2.6 mg kg-1), Pb (129-214 mg $\left.335 \mathrm{~kg}^{-1}\right), \mathrm{Ag}\left(0.20-0.63 \mathrm{mg} \mathrm{kg}^{-1}\right)$, with concentrations 3 to 14 times higher than those estimated in the 336 Seine River sediment collected in upper catchment areas.

337 Concentrations in sediment from the Marne tributary $(26,27)$ were in the same range of variations 338 than sediment collected just upstream and downstream of its confluence with the Seine River. 339 Only TI concentrations (0.31-0.38 $\left.\mathrm{mg} \mathrm{kg}^{-1}\right)$ were lower than in the Seine River sediment while one 340 sediment sample (26) exhibited a notably high $\mathrm{Cr}$ concentration (83 $\left.\mathrm{mg} \mathrm{kg}^{-1}\right)$.

341 The Orge tributary sediment $(20,21,22)$ exhibited lower $\mathrm{Cr}\left(16-19 \mathrm{mg} \mathrm{kg}^{-1}\right)$, Ni $\left(8-9 \mathrm{mg} \mathrm{kg}^{-1}\right)$, As 342 (2.4-2.7 mg kg-1), TI (0.22-0.28 mg kg-1) and similar Zn (78-152 mg kg-1), Cu (15-28 mg kg-1), Cd $343\left(0.3-0.5 \mathrm{mg} \mathrm{kg}^{-1}\right), \mathrm{Sb}\left(0.7-1.1 \mathrm{mg} \mathrm{kg}^{-1}\right), \mathrm{Pb}\left(25-52 \mathrm{mg} \mathrm{kg}^{-1}\right), \mathrm{Ag}\left(0.07-0.46 \mathrm{mg} \mathrm{kg}^{-1}\right)$ concentrations 344 compared to the sediment collected after its confluence with the Seine River.

345 The downstream Yvette sediment (19) systematically displayed higher concentrations than the 346 upstream Yvette sediment (17, 18). $\mathrm{Cr}\left(55 \mathrm{mg} \mathrm{kg}^{-1}\right), \mathrm{Ni}\left(21 \mathrm{mg} \mathrm{kg}^{-1}\right)$, As $\left(7.3 \mathrm{mg} \mathrm{kg}^{-1}\right)$, and Cd $(0.6$ $347 \mathrm{mg} \mathrm{kg}^{-1}$ ) metal contents were similar to those of sediment collected in the Seine River downstream 348 of the confluence while $\mathrm{Zn}\left(152 \mathrm{mg} \mathrm{kg}^{-1}\right), \mathrm{Cu}\left(68 \mathrm{mg} \mathrm{kg}^{-1}\right), \mathrm{Sb}\left(3.2 \mathrm{mg} \mathrm{kg}^{-1}\right), \mathrm{Pb}\left(83 \mathrm{mg} \mathrm{kg}^{-1}\right)$ and $349 \mathrm{Ag}\left(0.89 \mathrm{mg} \mathrm{kg}^{-1}\right)$ contents were higher and $\mathrm{TI}\left(0.41 \mathrm{mg} \mathrm{kg}^{-1}\right)$ contents lower. For the remaining 350 sediment $(17,18)$, their concentrations in $\mathrm{Cr}\left(34-45 \mathrm{mg} \mathrm{kg}^{-1}\right)$, Ni $\left(12-19 \mathrm{mg} \mathrm{kg}^{-1}\right)$ were similar to 351 those measured in downstream Seine River sediment while Zn (92-121 mg kg-1), Cu (25-30 mg $\left.352 \mathrm{~kg}^{-1}\right)$, As (4.1-4.5 mg kg-1), Cd (0.3 mg kg-1), Sb (0.8-1.0 mg kg-1), Pb (37-40 mg kg-1), Ag (0.19$\left.3530.33 \mathrm{mg} \mathrm{kg}^{-1}\right)$ and $\mathrm{Tl}\left(0.27-0.30 \mathrm{mg} \mathrm{kg}^{-1}\right)$ were lower.

354 Downstream of Paris, the Oise tributary sediment (28) was characterized by the highest $\mathrm{Cr}$ (68 $\left.355 \mathrm{mg} \mathrm{kg}{ }^{-1}\right)$ and $\mathrm{Ni}\left(31 \mathrm{mg} \mathrm{kg}^{-1}\right)$ concentrations although a lower Ag concentration $\left(0.26 \mathrm{mg} \mathrm{kg}^{-1}\right)$ 356 compared to downstream sediment of the Seine River. For the Eure tributary sediment (29), 
357 elemental concentrations were similar to those of the nearest Seine River sediment (16), except 358 for $\mathrm{Pb}$ showing a maximal value of $156 \mathrm{mg} \mathrm{kg}^{-1}$ and Tl exhibiting a lower value of $0.35 \mathrm{mg} \mathrm{kg}^{-1}$. 

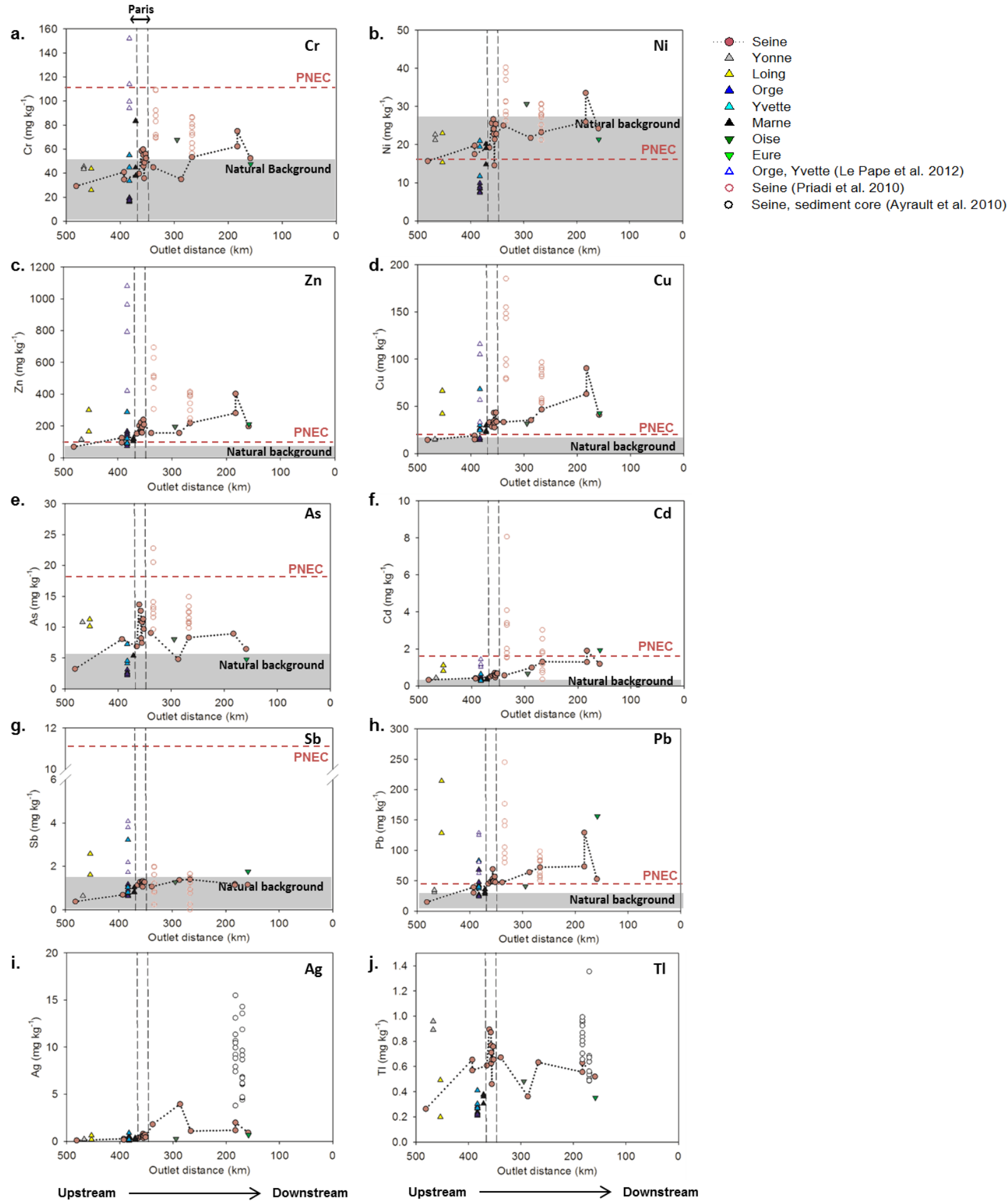

Figure 4. Spatial evolution of sediment trace element concentrations in the downstream direction along the Seine River. Circles with the dotted line corresponds to the Seine River samples and triangles to the tributary samples. Natural background and Predicted No Effect Concentrations (Barjhoux et al., 2016) for sediment are also presented. 


\subsubsection{Lead isotopes ratios}

${ }^{206} \mathrm{~Pb} /{ }^{207} \mathrm{~Pb}$ ratios measured in the Seine River sediment ranged between $1.1637 \pm 0.0030$ and $1.1847 \pm 0.0051$. In sediment collected in tributaries, ${ }^{206} \mathrm{~Pb} /{ }^{207} \mathrm{~Pb}$ isotopes ranged between 1.1422 \pm 0.0066 and $1.1838 \pm 0.0014$ (Figure 5, Table S3). Sediment from the Seine River was characterized by a decrease in $\mathrm{Pb}$ ratios associated with an increase in $\mathrm{Pb}$ concentrations in downstream direction. This reflects a change in sources, from the natural to the urban endmembers. The urban end-member corresponds to the signature of the $\mathrm{Pb}$ emitted by a Parisian waste water treatment plant. This signature is interpreted as a mixing of historical Parisian lead with lead from gasoline (Ayrault et al., 2012). The sediment collected in the Yonne, Marne and Oise tributaries had higher ${ }^{206 \mathrm{~Pb} / 207} \mathrm{~Pb}$ and $1 / \mathrm{EF}$ ratios compared to the Seine River sediment with ratios varying from $1.1728 \pm 0.0024$ in the Marne sediment (26) to $1.1838 \pm 0.0014$ in the Yonne sediment (23). To the contrary, sediment from the Orge, Yvette, Loing and Eure tributaries was characterized by lower $\mathrm{Pb}$ isotopic ratios ranging between $1.1422 \pm 0.0066$ for the Eure sediment (29) and $1.1744 \pm 0.0053$ for the Orge sediment (17). Sediment plotted well between the natural and urban end-members, with the exception of the Eure sediment (29), showing the lowest $\mathrm{Pb}$ ratio and likely impacted by the leaded gasoline end-member.

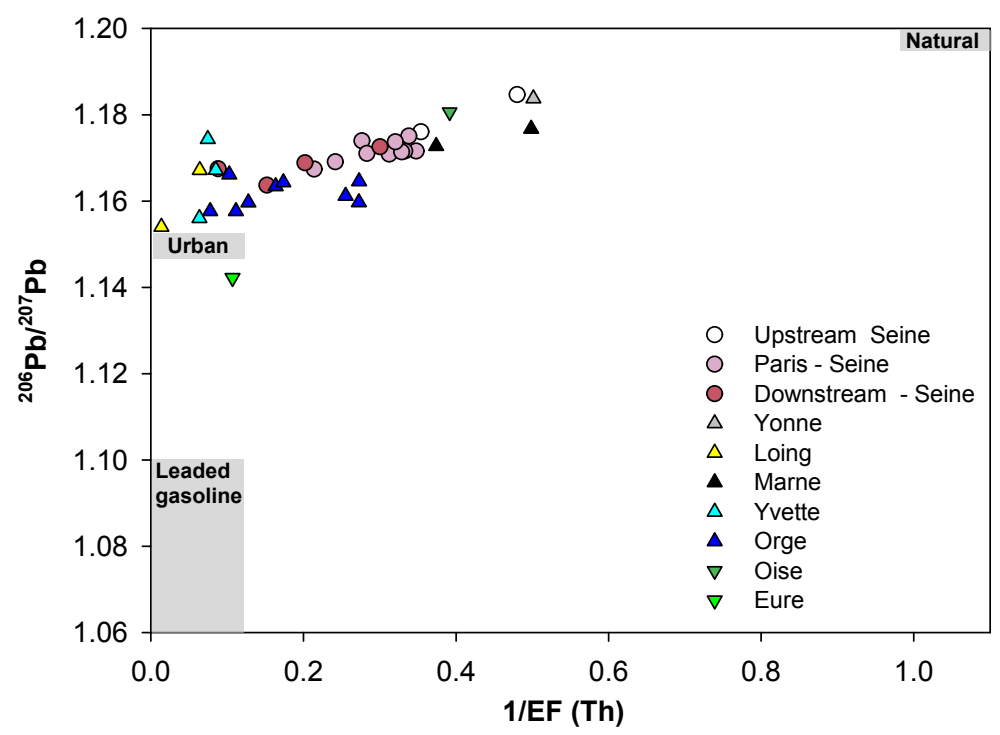

Figure $5 .{ }^{207} \mathrm{~Pb} / 206 \mathrm{~Pb}$ vs $1 / \mathrm{EF}$ in the sediment collected in the Seine River and its tributaries (uncertainty on ${ }^{207} \mathrm{~Pb} /{ }^{208} \mathrm{~Pb}$ ratio determination $\leq 0.5 \%$ ). Potential $\mathrm{Pb}$ sources, represented with grey boxes showing the variability of their ${ }^{208} \mathrm{~Pb} /{ }^{207} \mathrm{~Pb}$ ratio, include natural lead (Elbaz-Poulichet et al., 1986), urban lead (Ayrault et al., 


\subsubsection{Correlations and PCA}

390 A correlation analysis was conducted using the sediment major elemental and thorium 391 concentrations (Table 1). When analyzing those elements often used to correct data from potential 392 particle size effects, a significant correlation was observed between $\mathrm{Al}$ and $\mathrm{Th}(\mathrm{r}=0.72)$ while 393 correlations between $\mathrm{Ti}$ and $\mathrm{Al}(\mathrm{r}=0.51)$ and those between $\mathrm{Ti}$ and $\mathrm{Th}(\mathrm{r}=0.30)$ were less 394 significant. Considering those correlation values $>0.65$, Mn was the element that showed the most 395 significant correlations ( $\mathrm{Mn}$ and Th, r=0.68; $\mathrm{Mn}$ and $\mathrm{Mg}, \mathrm{r}=0.79$; $\mathrm{Mn}$ an Al, r=0.87, $\mathrm{Mn}$ and Fe, $396 \quad r=0.80)$ while Na displayed only a significant correlation with $\mathrm{Ca}(r=0.80)$.

397 Table 1. Spearman correlation matrix for major and thorium concentrations.

398

\begin{tabular}{llllllllll}
\hline & Th & $\mathrm{Na}$ & $\mathrm{Mg}$ & $\mathrm{Al}$ & $\mathrm{K}$ & $\mathrm{Ca}$ & $\mathrm{Ti}$ & $\mathrm{Mn}$ & $\mathrm{Fe}$ \\
\hline $\mathrm{Th}$ & 1.00 & 0.16 & $0.55^{* * *}$ & $0.72^{* * *}$ & $0.38^{*}$ & 0.13 & 0.30 & $0.68^{* * *}$ & $0.50^{* *}$ \\
$\mathrm{Na}$ & & 1.00 & 0.17 & 0.017 & $0.44^{*}$ & $0.80^{* * *}$ & $0.51^{* * *}$ & 0.11 & 0.22 \\
$\mathrm{Mg}$ & & & 1.00 & $0.77^{* * *}$ & 0.38 & 0.33 & $0.34^{*}$ & $0.79^{* * *}$ & $0.67^{* * *}$ \\
$\mathrm{Al}$ & & & & 1.00 & $0.50^{* * *}$ & 0.29 & $0.51^{* * *}$ & $0.87^{* * *}$ & $0.84^{* * *}$ \\
$\mathrm{~K}$ & & & & & 1.00 & $0.76^{* * *}$ & $0.93^{* * *}$ & 0.32 & 0.30 \\
$\mathrm{Ca}$ & & & & & & 1.00 & $0.80^{* * *}$ & 0.12 & 0.082 \\
$\mathrm{Ti}$ & & & & & & & 1.00 & 0.29 & 0.29 \\
$\mathrm{Mn}$ & & & & & & & 1.00 & $0.80^{* * *}$ \\
$\mathrm{Fe}$ & & & & & & & & 1.00 \\
\hline
\end{tabular}

${ }^{*}$ p-value $<0.05 ;{ }^{* *}$-value $<0.001 ;{ }^{* * *}$-value $<0.0001$

400 A PCA was performed on the radionuclide concentrations, ${ }^{206} \mathrm{~Pb} /{ }^{207} \mathrm{~Pb}$ ratios and metal 401 concentrations measured on the sediment samples $(n=29)$ (Figure 6). As Ti was not measured for 402 those sediment samples collected in the Orge River, this element was removed from further 403 analysis. Data were normalized to Th to remove potential particle size effects. The first component 404 (F1) accounted for $51.4 \%$ of the total variance, compared to $13.8 \%$ and $8.5 \%$ for the second and 405 third components, respectively. Three pools of parameters were discriminated based on this PCA: 406 the first group (As, $\mathrm{Tl}, \mathrm{Fe}, \mathrm{Al}, \mathrm{Ni}, \mathrm{Cr}, \mathrm{Mg}$ ) was characterized by positive $\mathrm{F} 1$ and $\mathrm{F} 2$ components, 407 the second group ( $\mathrm{Ag}, \mathrm{Zn}, \mathrm{Cu}, \mathrm{Cd}, \mathrm{K}, \mathrm{Sb}, \mathrm{Pb},{ }^{206} \mathrm{~Pb} /{ }^{207} \mathrm{~Pb}$ and $\mathrm{Na}$ ) was described by a positive $\mathrm{F} 1$ 408 component and a negative F2 component, whereas the third group ( $\left.\mathrm{Ca},{ }^{137} \mathrm{Cs},{ }^{7} \mathrm{Be}\right)$ was 409 represented by negative F1 and F2 components. The Orge $(17,18,19)$ and the Loing sediment 410 (24) samples were discriminated from the other samples by a positive correlation with the F1 411 component. 


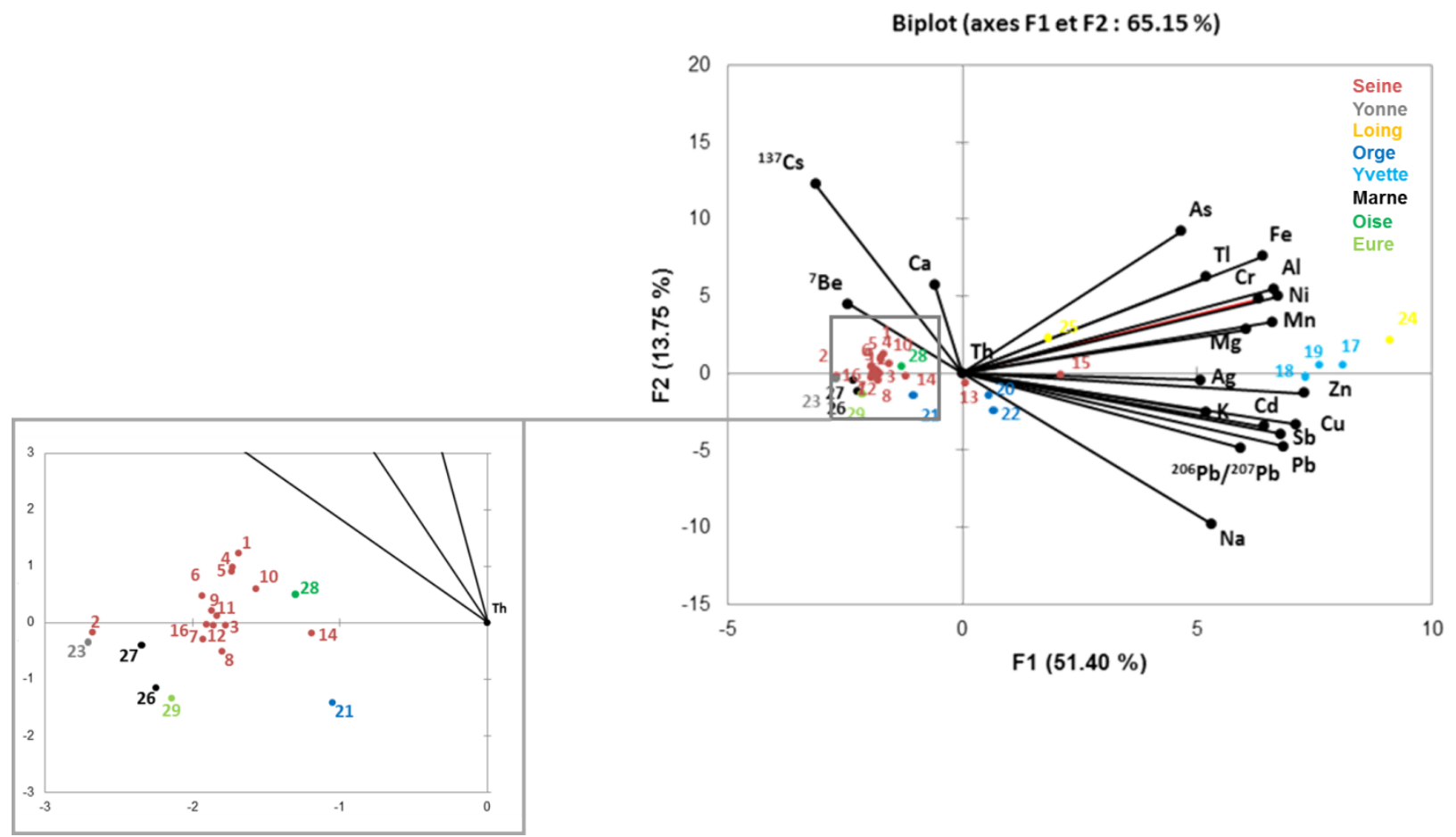

Figure 6. Results of the Principal Component Analysis performed on the sediment samples dataset (elemental and radionuclide concentrations, ${ }^{206} \mathrm{~Pb} / 207 \mathrm{~Pb}$ ratio) normalized to $\mathrm{Th}$.

\subsubsection{Enrichment Factors}

418 Enrichment factors (EF) were calculated to discriminate between the natural and anthropogenic 419 sources of metals/metalloids transported with sediment during the Seine River flood event (Figure 420 7).

421 For all the sediment collected along the Seine River and its tributaries, the following ranges of 422 values were obtained using Th normalization: $1.2<\mathrm{EF}(\mathrm{Cr})<7.6,1.1<\mathrm{EF}(\mathrm{Ni})<6.3,2.1<\mathrm{EF}(\mathrm{Zn})<19.1$, $423 \quad 2.1<\mathrm{EF}(\mathrm{Cu})<26.5, \quad 0.9<\mathrm{EF}(\mathrm{As})<6.8, \quad 1.8<\mathrm{EF}(\mathrm{Cd})<23.8, \quad 1.2<\mathrm{EF}(\mathrm{Sb})<19.8, \quad 1.7<\mathrm{EF}(\mathrm{Pb})<72.4$ 424 (Table S5). The highest EFs were observed for $\mathrm{Pb}, \mathrm{Cd}, \mathrm{Sb}$ and $\mathrm{Zn}$. When normalized to Al, very 425 similar trends although lower values were obtained (Table S5), with the highest EFs observed for $426 \mathrm{~Pb}, \mathrm{Cd}, \mathrm{Sb}$ and $\mathrm{Zn}$ (Table S6, Figure S1).

427 For each element/normalization, the highest EFs were systematically found in the sediment 428 collected in the Loing and Yvette Rivers. The lowest factors were observed in sediment collected 429 in Paris and its vicinity while downstream of Paris, sediment collected to Bouafle, in the Seine 430 River (15), exhibited higher EFs for $\mathrm{Zn}, \mathrm{Cu}, \mathrm{Cd}, \mathrm{Sb}$ and $\mathrm{Pb}$. For As, although the highest EFs were 431 observed in sediment collected in the Loing River $(24,25)$, this element exhibited a different trend 
432 with higher EFs in Paris and its vicinity $(1.6<E F(A s / T h)<2)$ compared to those values found in the 433 Yvette $(17,18,19)$ and Orge $(20,21,22)$ Rivers $(1<E F($ As/Th $)<1.4)$.

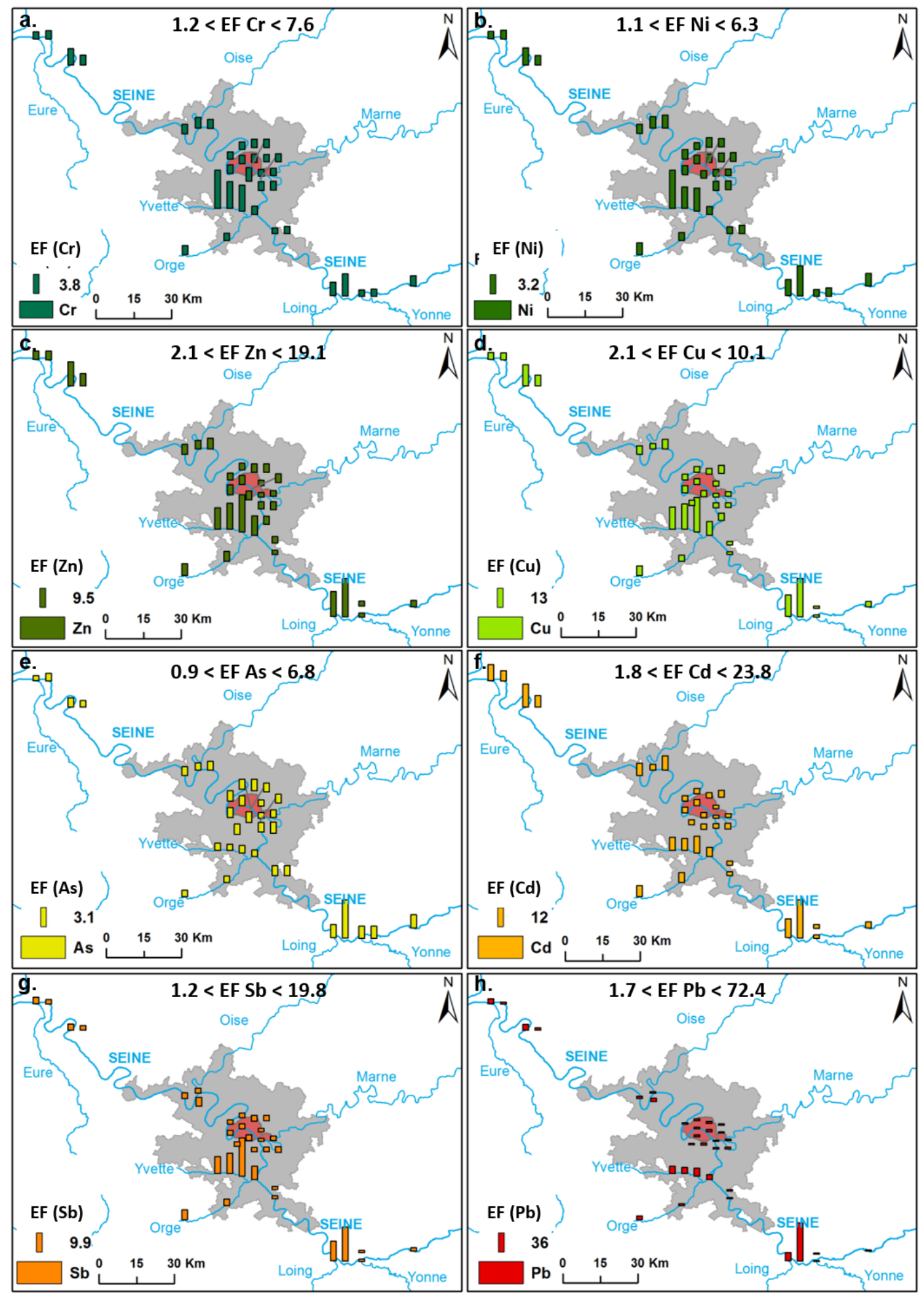

Figure 7. Enrichment Factors (EF) for $\mathrm{Cr}, \mathrm{Ni}, \mathrm{Zn}, \mathrm{Cu}, \mathrm{As}, \mathrm{Cd}, \mathrm{Sb}$ and $\mathrm{Pb}$ calculated for each sediment sample 436 collected along the Seine River and its main tributaries. EFs were calculated after Th normalization. 


\subsection{Particle size effect, normalization and carrier phases}

439 Metal and radionuclide concentrations need to be normalized to limit potential particle size effects 440 and provide meaningful interpretations of sediment contamination levels. Al, Ti, and $\mathrm{Si}$ are 441 commonly used to this end in the literature (Bouchez et al., 2011; Grosbois et al., 2012; 442 Quevauviller, 1989)). Although Th normalization was shown to be effective in a lowland river basin

443 of France and in the Seine River basin (Le Cloarec et al., 2011; Foucher et al., 2015), this 444 parameter is rarely used to this end. An inter-element correlation matrix was therefore used to 445 identify those alternative elements that may be used to correct sediment data from potential 446 particle size effects.

447 Ti was poorly correlated to Al and Th (section 3.4.1). Moreover, in urban catchments, the potential 448 release of $\mathrm{TiO}_{2}$ originating from paint and personal care products into the environment may 449 prevent its use as a conservative element. In the current research, a significant correlation was 450 observed between Th and $\mathrm{Al}(\mathrm{r}=0.72)$, suggesting that both elements are able to correct sediment 451 metal concentration from potential particle size effects. Al is a conservative element characteristic 452 of the fine sediment fraction and it is commonly used as a grain-size proxy to limit the dilution by 453 quartz, silica or calcite (Owens et al., 2005). Th is known to be preferentially fixed to fine particles 454 and can also be used for normalization (Le Cloarec et al., 2011; Foucher et al. 2015). Accordingly, 455 EFs were calculated using both elements for normalization. EFs calculated with Th were

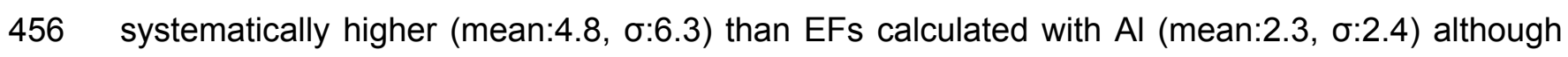
457 similar trends were observed with the highest and lowest EFs observed for the same sediment 458 samples when using both methods. Furthermore, Th was the only element available for the entire 459 dataset (i.e. sediment from the flood event and previous samples (Gateuille, 2013) used to 460 characterize the four end-members in the modelling approach). Accordingly, the following 461 discussion was restricted to those results corrected with Th.

462 After normalization to Th, a PCA was performed on the sediment metal and radionuclide contents 463 to better visualize correlations between elements and to examine in particular those elements that 464 may act as carrier phases (Figure 6). Most of the parameters contributed to the first component. 465 These parameters were scattered into two groups with respect to the second component (to which 466 Cs-137, Be-7, Ca are contributing). The group with a negative load on the second component is 467 composed of $\mathrm{Ag}, \mathrm{Zn}, \mathrm{Cu}, \mathrm{Pb}, \mathrm{Cd}$ and $\mathrm{Sb}$ that are well-known urban pollutants (Sutherland, 2000; 468 Marcheselli et al., 2010; Bi et al., 2011). 
The occurrence of $K$ in this group demonstrates the need to conduct further investigations regarding the mineralogical phases carrying this element. In the second group, As, $\mathrm{TI}, \mathrm{Cr}$ and $\mathrm{Ni}$ plotted close to $\mathrm{Fe}, \mathrm{Al}, \mathrm{Mg}$ and $\mathrm{Mn}$, indicating that $\mathrm{As}, \mathrm{TI}, \mathrm{Cr}$ and $\mathrm{Ni}$ could be carried by aluminosilicates and/or Fe or Mn oxyhydroxides. Furthermore, low EFs were calculated for $\mathrm{As}, \mathrm{Ni}, \mathrm{Cr}$ and $\mathrm{TI}$, suggesting that there is no longer significant contamination in these three elements in the Seine River Basin. This is consistent with previous findings reported in the literature (TI: Ayrault et al., 2010; other: Meybeck et al., 2016).

476 Trace urban elements $\mathrm{Ag}, \mathrm{Zn}, \mathrm{Cd}, \mathrm{Cu}, \mathrm{Sb}, \mathrm{Pb}$ are well correlated ( $r>0.88$ ) (Table S7) indicating 477 that they are likely supplied by the same sources. However, a lack of correlation between urban 478 elements and those characteristics of the clay fraction and oxyhydroxides was observed, 479 suggesting that other carrier species are involved. As shown by Le Pape et al. $(2013,2014)$ for $480 \mathrm{~Pb}$ and $\mathrm{Zn}$ respectively, changes in particulate speciation were observed suggesting that different 481 carrier phases may be associated to a given urban metal. Priadi et al. (2010) observed along the 482 Seine River that metal speciation may vary in downstream direction depending on the urban 483 pressure. Seasonal variations may also impact metal speciation with changes in contamination 484 sources and/or sediment diagenesis. All these processes may explain the lack of association 485 observed between urban metals and elements characteristic of alumino-silicates and/or (Fe, Mn) 486 oxyhydroxydes for the sediment collected during the Seine River flood.

487 Most sediment samples collected in the Seine River and its main tributaries plotted together and 488 were associated with ${ }^{7} \mathrm{Be},{ }^{137} \mathrm{Cs}$ and to a lesser extent with $\mathrm{Ca}$. ${ }^{7} \mathrm{Be}$ and ${ }^{137} \mathrm{Cs}$ are strongly fixed to 489 fine particles (Taylor, 2012). These sediment samples may be carried by carbonate phases. This 490 is consistent with the sedimentary nature of the Seine River basin that includes $78 \%$ of various 491 carbonate rocks such as chalk and limestone (Meybeck, 1999). Accordingly, the F2 component 492 tends to discriminate a natural source, suggesting that these sediment samples would originate 493 from the erosion of carbonate soils, characteristic of the geological nature of the Seine River basin. 494 The Orge $(17,18,19)$ and the Loing sediment $(24)$ samples were discriminated from the remaining 495 samples while being correlated to urban elements. This is consistent with the high EFs calculated 496 for these samples, suggesting a significant urban contamination. These results differ from previous 497 findings obtained in the Orge subcatchment (Le Pape et al. 2011) which showed that Zn and Cd 498 behave differently from the remaining urban elements $(\mathrm{Ag}, \mathrm{Cu}, \mathrm{Sb}, \mathrm{Pb})$ in suspended sediment 499 collected in this river (Le Pape et al., 2011). This suggests that during the flood of the Seine River, 500 Zn originated from a different source than during usual low-flow conditions. The flood sediment 501 investigated in the current research may be representative of a past and historical contamination 
compared to the present-day contamination of the Orge subcatchment investigated by Le Pape et

503 al. (2011). This interpretation is confirmed by radionuclide measurements that demonstrated that 504 sediment consisted of older remobilized particles in the Orge River.

\subsection{Metal contamination, short-term perspective}

506 Predicted No Effect Concentrations (PNECs) defining the toxicity of elements in the environment 507 were compared to the sediment metal concentrations (Barjhoux et al., 2016). PNECs are 508 determined by environmental institutions recognized at the European level. $\mathrm{Ni}, \mathrm{Zn}, \mathrm{Cu}$ and $\mathrm{Pb}$ 509 concentrations exceeded PNEC values in sediment collected along the Seine River and its 510 tributaries, highlighting the potential risk for the environment (Figure 4). Only the sediment 511 sampled in uppermost sections of the Seine River had concentrations lower than the PNEC 512 values. For $\mathrm{Cd}$, sediment concentrations remained lower than the PNEC value of $1.8 \mathrm{mg} \mathrm{kg}^{-1}$ with 513 the exception of one sediment sample, collected in the downstream section of the Seine River in 514 Bouafle (15), slightly exceeding this value with a Cd concentration of $1.9 \mathrm{mg} \mathrm{kg}^{-1}$. For $\mathrm{Cr}$, As and $515 \mathrm{Sb}$, sediment concentrations remained lower than the PNEC values, suggesting the absence of 516 an environmental toxicity.

517 In a review by Viers et al. (2009), mean concentrations of trace elements in suspended sediment 518 of World Rivers were provided, with a compilation of concentrations found in both pristine and 519 human-impacted rivers. Compared to this dataset, elemental concentrations of the Seine River 520 sediment were lower for $\mathrm{Cr}, \mathrm{Ni}, \mathrm{As}$ and $\mathrm{Sb}$ although in the same range for $\mathrm{Zn}, \mathrm{Cu}, \mathrm{Cd}, \mathrm{Pd}$ and $\mathrm{TI}$ 521 (Table 2). Elemental concentrations found in the Seine flood sediment were in good agreement 522 with those found in the Elbe and Ebro rivers (Baborowski et al., 2012; Roig et al., 2016) in Europe. 523 These analogies suggest similarities with other major rivers impacted by human activities. 524 However, the direct comparison of elemental concentrations measured in different catchments is 525 difficult and must be undertaken with much caution because different types of samples (i.e. 526 suspended particles, riverbed sediments, sediment cores) may be collected in different basins, 527 reflecting the contamination of different particle size fractions (i.e. bulk, $<2 \mathrm{~mm},<63 \mu \mathrm{m},<0.45$ $528 \mu \mathrm{m}$ ) during various hydrological conditions. Accordingly, the normalization of geochemical data to 529 a conservative element is required to enable comparison between different datasets. However, 530 identifying a universal conservative element is not straightforward (see section 3.4). Despite these 531 difficulties, comparing sediment metal concentrations is essential for environmental authorities to 532 estimate contamination levels and evaluate their impact on riverine environments.

533 It is important to note that elemental concentrations in sediment collected during snapshot 534 campaigns may reflect spatial and temporal variations, even over a short temporal period. 
535 Sampling lag deposits has the benefit to essentially integrate the falling limb of the hydrograph.

536 However, at the catchment scale, sediment may be characterized by a spatial variability that 537 depends on it physical, chemical and biological properties and potential for erosion (Haag et al., 538 2001; Baborowski et al., 2012). Accordingly, the sediment contamination patterns along the Seine 539 River and its tributaries could be partly explained by the nature of the deposited flood sediment.

540 Further investigations are required to comprehensively examine this perspective.

541 Another parameter that could be considered is the distribution of the metal contamination related 542 to hydrological parameters of the flood for each sampling location. Unfortunately, due to it sudden 543 and exceptional character, accurate flow measurements were not available but upstream 544 tributaries of the Seine River, such as the Loing River, were characterized by return periods $>50$ 545 years compared to the Seine River in Paris with return periods estimated to 10-20 years, 546 suggesting that the sediment metal contamination depends on the temporality of the flood and the 547 spatial distribution of rainfall.

548

549 
Table 2. Worldwide average concentrations of trace elements $\left(\mathrm{mg} \mathrm{kg}^{-1}\right)$ in sediment from major rivers of the world.

\begin{tabular}{|c|c|c|c|c|c|c|c|c|c|c|c|c|}
\hline River & Sample & Reference & Al & $\mathrm{Cr}$ & $\mathbf{N i}$ & $\mathrm{Zn}$ & $\mathrm{Cu}$ & As & Cd & $\mathrm{Sb}$ & $\mathrm{TI}$ & $\mathrm{Pb}$ \\
\hline Worldwide Rivers & & & 87200 & 130 & 75 & 208 & 76 & 36 & 1.6 & 2.2 & 0.5 & 61 \\
\hline South American Rivers & & & 91000 & 79 & 46 & 184 & 59 & - & - & - & - & 76 \\
\hline North American Rivers & & & 83000 & 115 & 50 & 137 & 34 & - & - & - & - & 22 \\
\hline Asian Rivers (Russia) & Suspended sediment $(<0.45 \mu \mathrm{m})$ & Viers et al. (2009) & 71000 & 260 & 123 & 300 & 145 & - & - & - & - & 35 \\
\hline Asian Rivers (China) & & & 95000 & 117 & 68 & 145 & 53 & - & - & - & - & 64 \\
\hline African Rivers & & & 113000 & 130 & 78 & 130 & 53 & - & - & - & - & 46 \\
\hline European Rivers & & & 61000 & 164 & 66 & 346 & 172 & - & - & - & - & 71 \\
\hline Upper Continental Crust & Rocks & Taylor \& McLennan (1995) & 80400 & 35 & 20 & 71 & 25 & - & 0.1 & 0.2 & 0.8 & 20 \\
\hline Parana River (Brazil) & Suspended sediment $(<0.45 \mu \mathrm{m})$ & Campodonico et al. (2014) & $\begin{array}{l}17.9 \% \\
\left(\mathrm{Al}_{2} \mathrm{O}_{3}\right)\end{array}$ & 128 & 45 & - & 80 & - & - & - & 0.63 & 28 \\
\hline $\begin{array}{l}\text { Uruguay River } \\
\text { (Argentina) }\end{array}$ & River sediment (bulk) & Tatone et al. (2016) & - & 19 & 16 & 85 & 55 & - & - & - & - & 13 \\
\hline Mississippi River (USA) & Suspended sediment & Horowitz et al. (2008) & 54667 & 67 & 41 & 93 & 21 & 9 & 0.5 & 2.4 & - & 26 \\
\hline Mekong River (Asia) & Suspend sediment $(<0.45 \mu \mathrm{m})$ & Cenci et al. (2004) & 90000 & 39 & 25 & - & - & 18 & - & - & - & - \\
\hline Jiaozhou Bay (China) & River sediment (bulk) & Xu et al. (2017) & 135000 & 69 & - & 65 & 24 & 8 & 0.2 & - & - & 20 \\
\hline Nile River (Egypt) & River sediment (bulk) & Badawy et al. (2017) & 43360 & 173 & 48 & 74 & - & 1 & 0.3 & 0.2 & - & - \\
\hline Congo River (Congo) & Suspended sediment $(<0.2 \mu \mathrm{m})$ & Dupré et al. (1996) & - & 121 & 86 & - & - & - & - & - & - & 36 \\
\hline Elbe River (Germany) & Sediment core (upper layer, 0-5 cm, $<2 \mathrm{~mm}$ ) & Baborowski et al. (2012) & - & - & 22 & 473 & 63 & 24 & - & - & - & 82 \\
\hline Ebro River (Portugal) & River sediment (bulk) & Roig et al. (2016) & - & 36 & 14 & 87 & 22 & 6 & 0.3 & - & - & 17 \\
\hline PNEC values & Sediment & Barjhoux et al. (2016) & - & 110 & 17 & 93 & 22 & 17 & 1.8 & 11.2 & - & 47 \\
\hline $\begin{array}{l}\text { Seine River, June } 2016 \\
\text { flood event }\end{array}$ & Sediment $(<63 \mu \mathrm{m})$ & This study & $\begin{array}{l}12900- \\
46890 \\
\end{array}$ & $\begin{array}{l}16- \\
75 \\
\end{array}$ & $\begin{array}{l}8- \\
34 \\
\end{array}$ & $\begin{array}{l}69- \\
402 \\
\end{array}$ & $\begin{array}{l}14- \\
90 \\
\end{array}$ & $\begin{array}{l}2- \\
14 \\
\end{array}$ & $\begin{array}{l}0.3- \\
1.9 \\
\end{array}$ & $\begin{array}{l}0.4- \\
3.2 \\
\end{array}$ & $\begin{array}{c}0.2- \\
0.9 \\
\end{array}$ & $\begin{array}{r}15- \\
214 \\
\end{array}$ \\
\hline $\begin{array}{l}\text { Seine River basin, } \\
\text { natural contents }\end{array}$ & Sediment & $\begin{array}{l}\text { Le Cloarec et al. (2011) } \\
\text { Thévenot et al. (2007) }\end{array}$ & 36535 & 52 & 27 & 76 & 14 & 5.5 & 0.3 & 0.8 & - & 26 \\
\hline
\end{tabular}


554 In a longer time perspective, $\mathrm{Cr}, \mathrm{Zn}, \mathrm{Cu}, \mathrm{Cd}, \mathrm{Sb}, \mathrm{Pb}, \mathrm{Ni}$ and As concentrations measured in the 555 sediment from the Orge River, and from the Seine River in Puteaux (12) and Vernouillet (14) may 556 be compared to those measured in samples collected at the same locations or in their immediate 557 vicinity (Priadi et al., 2011b; Le Pape et al., 2012) (Figure 4). As sediment was sieved to $63 \mu \mathrm{m}$, 558 elemental concentrations are compared to those of suspended particulate matter (SPM) samples. 559 For the Orge River, the sediment elemental concentrations from the June 2016 flood event were 560 lower than those found in the SPM collected between June 2010, and April 2011 (Le Pape et al., 561 2012). For the Seine River, the sediment elemental concentrations were lower (for $\mathrm{Cr}, \mathrm{Ni}, \mathrm{Zn}, \mathrm{Cu}$, 562 As, Cd, Pb in Puteaux (12) and Cr, Zn, Cu, As in Vernouillet (14)) or in the same range of variation 563 (for $\mathrm{Sb}$ in Puteaux (12) and for $\mathrm{Ni}, \mathrm{Cd}, \mathrm{Sb}, \mathrm{Pb}$ in Vernouillet (14)) than those measured in the SPM 564 collected between December, 2008, and September, 2009, in Bougival, located a few kilometers 565 downstream of Puteau and Triel, on the opposite bank of Vernouillet (Priadi et al., 2011b). This 566 dataset demonstrates that elemental concentrations ( $\mathrm{Cr}, \mathrm{Ni}, \mathrm{Zn}, \mathrm{Cu}, \mathrm{As}, \mathrm{Cd}, \mathrm{Sb}, \mathrm{Pb}, \mathrm{As}$ and $\mathrm{TI})$ 567 measured in the sediment from the June 2016 flood event remained lower or similar to those 568 monitored from 2003 to 2011 in the same areas. Despite local inputs, such as those from the 569 Orge, Yvette and Loing tributaries, metal and metaloid signatures were significantly diluted in the 570 Seine River during the 2016 flood event.

571 As the Seine River contamination has been well documented since the 1970s, trace element 572 concentrations (especially $\mathrm{Cd}, \mathrm{Cu}, \mathrm{Zn}, \mathrm{Pb}$, known as effective urban tracers in the Seine 573 catchment, e.g. Thévenot et al. 2007) measured in sediment from the June 2016 flood can be 574 placed in an historical contamination perspective. Analyses carried out between 1974 and 2000 575 on sedimentary archives, SPM and flood deposit samples showed an overall decline of $\mathrm{Cd}, \mathrm{Cr}$, $576 \mathrm{Cu}, \mathrm{Ni}, \mathrm{Pb}$ and $\mathrm{Zn}$ contents (Horowitz et al., 1999; Meybeck et al., 2007), with the Ni values similar 577 to the geochemical background. Similarly, metal concentrations in flood deposits collected 578 between 1994 and 2000 along the Seine River and its main tributaries (Yonne, Marne, Oise) were 579 higher compared to those measured in sediment from the June 2016 flood event, indicating the 580 occurrence of a significant decontamination (Table 2) (Grosbois et al., 2006). 
Table 3. $\mathrm{Zn}, \mathrm{Cu}, \mathrm{Cd}$ and $\mathrm{Pb}$ concentrations $\left(\mathrm{mg} \mathrm{kg}^{-1}\right)$ measured in flood deposits collected between 1994 and 2000 (from Grosbois et al., 2006, median values presented here) and in the June 2016 sediment (median values for the Paris sediment).

\begin{tabular}{lcccc}
\hline & Zn & Cu & Cd & Pb \\
\hline Paris (1994-2000) & 280 & 69 & 1.0 & 110 \\
Paris (June 2016) & 188 & 33 & 0.3 & 51 \\
Poses (1994-2000) & 350 & 83 & 1.9 & 110 \\
Poses (June 2016) & 198 & 41 & 1.2 & 53 \\
\hline
\end{tabular}

588 These results are consistent with the interpretation of the lead isotopic signatures measured in the 589 June 2016 sediment and show an increasing gradient of urban contamination in a downstream 590 direction across the Seine River catchment together with the progressive decontamination of the 591 Seine River catchment through time. Indeed, the Bouafle sediment core, located in the 592 downstream section of the Seine River, indicated that since the end of the 1990s, lead signatures 593 evolved from an urban to a natural source end-member (Ayrault et al., 2012). The lead signatures 594 measured in the sediment collected in Bouafle after the June 2016 flood were even higher than 595 that measured in the uppermost layer of the sediment core, further supporting the occurrence of 596 a strong decontamination trend.

$597 \mathrm{Ag}$ and $\mathrm{TI}$ contents may also be compared to the historical records deduced from the Bouafle 598 sediment core (Ayrault et al., 2010). The 2016 flood sediment collected at Bouafle had an Ag 599 concentration of $2.0 \mathrm{mg} \mathrm{kg}^{-1}$, lower than the $3.8 \mathrm{mg} \mathrm{kg}^{-1}$ measured in the 2003 sediment layer 600 (Figure 4i). The highest Ag sediment concentration in the 2016 flood was $3.95 \mathrm{mg} \mathrm{kg}^{-1}$ in Conflans601 St-Honorine (13) and was similar to the value found in the core in 2003. This suggests that in 602 downstream sections of the Seine River, Ag contamination has decreased during the last 15 years 603 despite the potential local supply of Ag contamination to the river network. The 'Seine Aval' 604 wastewater treatment plant, located less than $10 \mathrm{~km}$ upstream of the Conflans-St-Honorine 605 sampling location (13) treats $\sim 70 \%$ of the wastewater of the Parisian agglomeration (SIAAP). 606 Accordingly, the highest Ag concentration (3.95 mg kg-1) measured at Conflans-St-Honorine (13) 607 may be related to the release of treated wastewater upstream of the Seine-Oise confluence. For 608 the Oise sediment, the $\mathrm{Ag}$ content only reached $0.26 \mathrm{mg} \mathrm{kg}^{-1}$. Downstream of the Seine-Oise 609 confluence, the Ag content in sediment decreased from $3.95 \mathrm{mg} \mathrm{kg}^{-1}$ to $1.10 \mathrm{mg} \mathrm{kg}^{-1}$, suggesting 610 a dilution of the Ag sediment contamination by the Oise River sediment.

611 Once again, these findings highlight that the 'Seine Aval' wastewater treatment plant is a 612 significant source of Ag contamination of the Seine River (Ayrault et al., 2010). TI sediment 613 concentrations, ranging between 0.20 and $0.96 \mathrm{mg} \mathrm{kg}^{-1}$, remained in the same range of variations 614 as those found in the Bouafle sediment core (0.66 to $\left.1.01 \mathrm{mg} \mathrm{kg}^{-1}\right)$, demonstrating the absence of 
615 specific TI contamination during the 2016 flood event compared to the TI records over the last 70 616 years, even in Paris where the highest TI concentrations were measured (Figure 4j). These data 617 confirm the absence of $\mathrm{TI}$ contamination through the Seine catchment as reported by Tremel et 618 al. (1997) and Ayrault et al. (2010).

619 As previously mentioned, the normalization of elemental concentrations to a conservative 620 element, such as Th, is required to compare different geochemical datasets. Accordingly, EFs 621 calculated for the June 2016, flood event were compared to those estimated for the contamination 622 records reconstructed for the period 1943-2003 based on the analysis of the Bouafle sediment 623 core (Le Cloarec et al., 2011) (Table 4). EFs were the highest between 1958 and 1960 due to the 624 economic development following World War II. Then, EFs continuously decreased as a result of 625 the evolution of industrial production processes, the implementation of wastewater treatment 626 plants and environmental policies, leading to the progressive metal decontamination of the Seine 627 River catchment. Mean EFs estimated for the June 2016, flood event in the Seine River were 628 lower for $\mathrm{Cr}, \mathrm{Cu}, \mathrm{As}, \mathrm{Cd}$ and in the same range of values for $\mathrm{Zn}, \mathrm{Sb}$ and $\mathrm{Pb}$ than those estimated 629 in sediment that deposited in Bouafle in 2003 (Le Cloarec et al., 2011) (Table 3). This indicated 630 that despite the progressive decontamination of the Seine River, also observed in Meybeck et al. 631 (2007) and Le Cloarec et al. (2011) from 1950 to 2005 and more recently in the urban Orge 632 subcatchment from 2000 to 2010 (Le Pape et al. 2012), major flood events may remobilize and 633 export contaminated material characterized by EFs similar to those obtained more than 10 years 634 ago.

635 EFs of the sediment collected in the Seine tributaries reached even higher values than those 636 calculated for the sediment that deposited in the 1950s and 1960s. This is the case for $\mathrm{Sb}$ and $\mathrm{Pb}$, 637 with the highest $E F s$ estimated for the Yvette $\left(E F_{S b}=19.8\right)$ and Loing $\left(E F_{P b}=72.4\right)$ tributaries. These 638 results suggest the contribution of local inputs of contaminated sediment to the Seine River. $639{ }^{206} \mathrm{~Pb} /{ }^{207} \mathrm{~Pb}$ signatures may support this hypothesis. Accordingly, the urban signature of the Loing 640 sediment is distinguishable from the remaining lead signatures. This tributary was strongly 641 impacted by the June 2016 flood, with the highest water specific discharges and the most 642 devastating effect. Local urban sources such as the overflowing from wastewater treatment plant 643 may have contributed to this specific signature. In the same way, the Eure sediment exhibited the 644 lowest isotopic signature, suggesting a strong anthropogenic contamination that may be attributed 645 to elevated $\mathrm{Pb}$ concentrations in the Eure sediment due to the release of local industries (battery 646 plant) as observed in previous studies (Meybeck et al., 2004; Chiffoleau and Sonke, 2012), 647 corroborating the low ${ }^{206} \mathrm{~Pb} /{ }^{207} \mathrm{~Pb}$ signature measured in June 2016 . The single use of elemental 
648 concentrations did not highlight these results while EFs supported the investigation of 649 contamination levels at the catchment scale, with the direct comparison of samples collected at 650 different locations throughout time.

651 Table 4. EFs (Th normalization) estimated for the sediment from the June 2016 flood event and for the sediment 652 from the Bouafle sediment core (Le Cloarec et al., 2011)

\begin{tabular}{|c|c|c|c|c|c|c|c|c|c|}
\hline & & $\mathrm{EF}(\mathrm{Cr})$ & EF (Ni) & $E F(Z n)$ & $E F(C u)$ & EF (As) & $E F(C d)$ & $E F(S b)$ & $\mathrm{EF}(\mathrm{Pb})$ \\
\hline \multirow{3}{*}{$\begin{array}{l}\text { June } 2016 \\
\text { Seine River }\end{array}$} & Min & 1.2 & 1.1 & 2.2 & 1.8 & 1.2 & 2.3 & 1.5 & 2.0 \\
\hline & Max & 3.3 & 2.8 & 12.1 & 14.7 & 2.1 & 14.4 & 4.6 & 11.3 \\
\hline & Mean & 1.7 & 1.6 & 4.6 & 4.9 & 1.7 & 4.8 & 2.6 & 4.0 \\
\hline \multirow{3}{*}{$\begin{array}{c}\text { June } 2016 \\
\text { Seine tributaries }\end{array}$} & Min & 1.3 & 1.1 & 2.1 & 1.6 & 0.9 & 1.8 & 1.2 & 1.7 \\
\hline & Max & 7.6 & 6.3 & 19.1 & 26.5 & 6.8 & 23.8 & 19.8 & 72.4 \\
\hline & Mean & 2.8 & 2.3 & 7.7 & 9.4 & 1.8 & 7.0 & 6.5 & 11.5 \\
\hline \multirow{3}{*}{$\begin{array}{c}\text { Bouafle } \\
\text { sediment core }\end{array}$} & Min & 2 & - & 5 & 6 & 3 & 9 & 3 & 4 \\
\hline & Max & 7 & - & 29 & 41 & 6 & 188 & 15 & 29 \\
\hline & Surface layer & 2 & - & 5 & 6 & 3 & 9 & 3 & 4 \\
\hline
\end{tabular}

\subsection{Sediment sources and metal contamination}

656 The anthropogenic pressure of the June 2016 flood event was investigated using EFs to focus on 657 the sediment metal contamination and radionuclides to examine the spatial variation of their 658 sources. In upper catchment areas, the sediment from Bray-sur-Seine (01) mainly originated from 659 the remobilization (59\%) of subsurface (69\%) sources. EFs were low and ranged between 1.7 for $660 \mathrm{Sb}$ and 3.7 for $\mathrm{Cu}$. This sediment, collected upstream of the Yonne and Loing Rivers was not 661 significantly affected by the June 2016 flood event and would be representative of the baseline 662 Seine contamination level during low flow periods.

663 In the sediment collected in the Yonne and Loing tributaries, surface and subsurface sources were 664 well balanced (mean surface contribution of $47 \pm 4 \%$ ) with a strong remobilization of particles 665 (mean value of $70 \pm 3 \%$ ). EFs for the Yonne River sediment were systematically lower than 2.2, 666 suggesting minimal or moderate pollution, with elemental concentrations reflecting the local 667 geochemical background. In the Loing River, characterized by the highest water specific 668 discharges, elevated EFs in $\mathrm{Zn}$ (19.1), As (6.8), Cd (23.8), Pb (72.4) were estimated for deposited 669 sediment. Accordingly, depending on the element considered, the Loing River may be considered 670 as significantly to extremely polluted. This extreme pollution may likely be related to the extensive 671 flooding in this area, which was a $50 \mathrm{yr}$ return interval event. 
672 In the Orge and Yvette tributaries, sediment transported during the flood mainly consisted of 673 remobilized subsurface material, relatively enriched in metals. These particles may have been 674 eroded from channel banks following dam removal conducted in the Orge and Yvette catchments 675 since 2010 in the context of the ecological remediation of water bodies. The removal of these 676 structures, by increasing water velocity, facilitated the flush of the previously deposited particles, 677 creating new erosion and deposition areas. The highest EFs in Cr (7.6), Ni (6.3) and Sb (19.8) 678 were estimated for these two tributaries that can be characterized as significantly to highly 679 polluted. Although Sb indicates the current contribution of urban contamination, this is not the case 680 for $\mathrm{Cr}$ and $\mathrm{Ni}$ that likely originate from past industrial activities (1850-1950).

681 For sediment collected in Paris or in its vicinity, recently eroded surface sources dominated. This 682 contribution may be explained by urban runoff, especially from parks and gardens. The second 683 sediment source corresponds to the remobilization of particles originating both from the surface 684 and the subsurface with varying contributions. EFs estimated for the Parisian sediment were low 685 compared to those obtained in upstream tributaries such as the Loing, the Orge or the Yvette, with 686 most of the EFs lower than 5, suggesting a moderate metal enrichment and pollution of the Seine 687 River. Surprisingly, As and TI peaks were observed for these sediment samples, suggesting the 688 contribution of local sources, as their contents decreased again downstream of Paris.

689 For the Oise and Eure Rivers, the recently eroded surface contribution to the sediment was the 690 highest. These two tributaries drain agricultural areas. Accordingly, the elevated contribution of 691 surface particles may be explained by the erosion of agricultural soils, labelled with ${ }^{7} \mathrm{Be}$ from the 692 rainfall of June 2016 . These eroded particles, enriched in ${ }^{7} \mathrm{Be}$, transited via the river network during 693 the flood and likely settled during the falling limb. These trends were also observed for two 694 sediment samples in the downstream section of the Seine River $(14,16)$. However, the 695 contribution of local sources may be observed downstream of the Seine River $(13,15)$ with the 696 supply of high proportions of remobilized subsurface particles. The local occurrence of channel 697 bank collapse after the flood may explain these high subsurface contributions. EFs estimated for 698 the downstream Seine River sediment were higher than those estimated in Paris, mainly for $\mathrm{Zn}$, $699 \mathrm{Cu}, \mathrm{Cd}, \mathrm{Pb}$, recognized as urban contamination tracers in the Seine catchment (Thévenot et al., 700 2007; Le Pape et al., 2012). These high EFs, ranging between 5.1 and 14.7, suggest that either 701 contaminated particles were transported over long distances, down to Bouafle (15) where the 702 meanders of the Seine River may allow particles to settle or previously deposited contaminated 703 particles were remobilized. 
704 Accordingly, even if the June 2016 flood event generated high amounts of sediment, trace element 705 concentrations and EFs remained lower or in the same range of variations than those estimated 706 in similar material during the last decades along the Seine River. It demonstrates the progressive 707 decontamination of the Seine River sediment and the dilution effect of the flood, although local 708 inputs of remobilized and highly contaminated sediment from tributaries may have occurred in 709 some urban areas, particularly those that had the highest rainfall and discharges.

\section{Conclusions}

711 This study demonstrated the utility of collecting lag deposits to characterize the impact of a major 712 flood event on the river sediment contamination and the utility of coupling radionuclides and 713 elemental geochemistry to quantify sediment and contamination sources in highly urbanized 714 catchments. During this event, an increase in metal contents was observed in a downstream 715 direction with a high contaminant contribution from upper tributaries such as the Loing, Orge and 716 Yvette Rivers characterized by urban signatures and corresponding to the remobilization of older 717 sediment. In Paris and in downstream sections of the Seine River, the contribution of recently 718 eroded particles to the sediment dominated with an increasing contribution from urban runoff in 719 Paris and from the erosion of agricultural soils downstream of Paris.

720 Despite the exceptional nature of the flood, the sediment transiting the Seine River did not exhibit 721 excessive contamination levels with most of the EFs indicative of moderate pollution, suggesting 722 a dilution effect through the basin. Compared to historical records, the heavy metal contents of 723 the sediment transported during the 2016 flood remained lower than those measured since the 724 1970s, reflecting the progressive metal decontamination ongoing in the Seine River basin. Even 725 if the sediment metal contents are no longer characteristic of highly contaminated areas, $\mathrm{Ni}, \mathrm{Zn}$, $726 \mathrm{Cu}$ and $\mathrm{Pb}$, sediment concentrations exceeded PNEC values. Accordingly, in the framework of 727 Paris' candidacy to host the 2024 Summer Olympics with nautical competitions expected in the

728 Seine River, attention should focus on the toxicity of these elements for the environment.

729 To discriminate specific mineralogical inputs related to this exceptional flood event, further 730 investigations should be conducted to characterize the speciation of trace elements and their 731 carrying phases. These findings could then be compared to those obtained in previous studies 732 conducted on sediment collected during low-flow hydrological conditions. To improve the 733 understanding of the impact of major flood events on sediment quality in urbanized basins such 734 as the Seine River, continuous monitoring programs should be implemented. To ensure that water 735 quality criteria are sufficient for events organized in the Seine River, attention should also focus 
736 on the analysis of organic contaminants such as polycyclic aromatic hydrocarbons,

737 polychlorobiphenyls or poly and perfluoroalkyl substances and microbial communities in sediment.

\section{Acknowledgements}

740 This work received financial support from the Seine-Normandie Water Agency (no 1065961 (1) 2016) and was conducted in the framework of PIREN-Seine long term environmental monitoring and research programs. The authors would like to thank Louise Bordier for technical assistance with ICP-MS measurements and Claire Froger for the urban runoff sampling.

\section{4}

745

746

747

748

749

750

751

752

753

754

755

756

757

758

759

760

761

762

763

764

765

766

767

768

769

770

771

772

773

774

775

776

777

778

779

\section{References}

Ayrault, S., Priadi, C.R., Evrard, O., Lefevre, I., Bonte, P., 2010. Silver and thallium historical trends in the Seine River basin. Journal of Environmental Monitoring, 12(11), 2177-85. 10.1039/c0em00153h.

Ayrault, S., Roy-Barman, M., Le Cloarec, M.F., Priadi, C.R., Bonte, P., Gopel, C., 2012. Lead contamination of the Seine River, France: geochemical implications of a historical perspective. Chemosphere, 87(8), 902-10. 10.1016/j.chemosphere.2012.01.043.

Baborowski, M., Buttner, O., Morgenstern, P., Jancke, T., Westrich, B., 2012. Spatial variability of metal pollution in groyne fields of the Middle Elbe - implications for sediment monitoring. Environmental Pollution, 167, 115-23. 10.1016/j.envpol.2012.03.046.

Baborowski, M., Einax, J.W., 2016. Flood-event based metal distribution patterns in water as approach for source apportionment of pollution on catchment scale: Examples from the River Elbe. Journal of Hydrology, 535, 429-437. 10.1016/j.jhydrol.2016.01.077.

Badawy, W.M., Ghanim, E.H., Duliu, O.G., El Samman, H., Frontasyeva, M.V., 2017. Major and trace element distribution in soil and sediments from the Egyptian central Nile Valley. Journal of African Earth Sciences, 131, 53-61. 10.1016/j.jafrearsci.2017.03.029.

Barjhoux, I. et al., 2016. Application of a multidisciplinary and integrative weight-of-evidence approach to a 1-year monitoring survey of the Seine River. Environmental Science and Pollution Research. 10.1007/s11356-016-6993-6.

Bi, X., Li, Z., Zhuang, X., Han, Z., Yang, W., 2011. High levels of antimony in dust from ewaste recycling in southeastern China. Science of the Total Environment, 409(23), 5126-8. 10.1016/j.scitotenv.2011.08.009.

Bindler, R., Renberg, I., Rydberg, J., Andren, T., 2009. Widespread waterborne pollution in central Swedish lakes and the Baltic Sea from pre-industrial mining and metallurgy. Environmental Pollution, 157(7), 2132-41. 10.1016/j.envpol.2009.02.003.

Blake, W.H., Walsh, R.P.D., Barnsley, M.J., Palmer, G., Dyrynda, P., James, J.G., 2003. Heavy metal concentrations during storm events in a rehabilitated industrialized catchment. Hydrological Processes, 17(10), 1923-1939. 10.1002/hyp.1218.

Bouchez, J., Gaillardet, J., France-Lanord, C., Maurice, L., Dutra-Maia, P., 2011. Grain size control of river suspended sediment geochemistry: Clues from Amazon River depth profiles. Geochemistry, Geophysics, Geosystems, 12(3). 10.1029/2010gc003380.

Bradley, S.B., Cox, J.J., 1990. The significance of the floodplain to the cycling of metals in the river Derwent Catchment, U.K. Science of the Total Environment, 97-98, 441-454.

Bur, T., Probst, J.L., N'guessan, M., Probst, A., 2009. Distribution and origin of lead in stream sediments from small agricultural catchments draining Miocene molassic deposits (SW France). Applied Geochemistry, 24(7), 1324-1338. 10.1016/j.apgeochem.2009.04.004. 
Campodonico, V.A., García, M.G., Pasquini, A.I., 2016. The geochemical signature of suspended sediments in the Parana River basin: Implications for provenance, weathering and sedimentary recycling. Catena, 143, 201-214. 10.1016/j.catena.2016.04.008.

Cánovas, C.R., Hubbard, C.G., Olías, M., Nieto, J.M., Black, S., Coleman, M.L., 2008. Hydrochemical variations and contaminant load in the Río Tinto (Spain) during flood events. Journal of Hydrology, 350(1-2), 25-40. 10.1016/j.jhydrol.2007.11.022.

Carter, J., Walling, D.E., Owens, P.N., Leeks, G.J.L., 2006. Spatial and temporal variability in the concentration and speciation of metals in suspended sediment transported by the River Aire, Yorkshire, UK. Hydrological Processes, 20(14), 3007-3027. 10.1002/hyp.6156.

Cenci, R.M., Martin, J.M., 2004. Concentration and fate of trace metals in Mekong River delta. Science of the Total Environment, 332(1-3), 167-82. 10.1016/j.scitotenv.2004.01.018.

Chiffoleau, J.-F., Sonke, J.E., 2012. ISOMET, Etude de la signature isotopique des métaux dans l'estuaire de la Seine. Une information essentielle pour le traçage et la discrimination des sources de processus.

Cobelo-Garcia, A., Prego, R., Labandeira, A., 2004. Land inputs of trace metals, major elements, particulate organic carbon and suspended solids to an industrial coastal bay of the NE Atlantic. Water Research, 38(7), 1753-64. 10.1016/j.watres.2003.12.038.

Coynel, A., Blanc, G., Marache, A., Schafer, J., Dabrin, A., Maneux, E., Bossy, C., Masson, M., Lavaux, G., 2009. Assessment of metal contamination in a small mining- and smelting-affected watershed: high resolution monitoring coupled with spatial analysis by GIS. Journal of Environmental Monitoring, 11(5), 962-76. 10.1039/b818671e.

Coynel, A., Schäfer, J., Blanc, G., Bossy, C., 2007. Scenario of particulate trace metal and metalloid transport during a major flood event inferred from transient geochemical signals. Applied Geochemistry, 22(4), 821-836. 10.1016/j.apgeochem.2006.10.004.

Dominik, J., Burrus, D., Vernet, J.-P., 1987. Transport of the environmental radionuclides in an alpine watershed. Earth and Planetary Science Letters, 84, 165-180.

Du Laing, G., Rinklebe, J., Vandecasteele, B., Meers, E., Tack, F.M., 2009. Trace metal behaviour in estuarine and riverine floodplain soils and sediments: a review. Science of the Total Environment, 407(13), 3972-85. 10.1016/j.scitotenv.2008.07.025.

Dupré, B., Gaillardet, J., Rousseau, D., Allègre, C.J., 1996. Major and trace elements of riverborne material: The Congo Basin. Geochimica et Cosmochimica Acta, 60(8), 1301-1321.

Elbaz-Poulichet, F., Holliger, P., Martin, J., Petit, D., 1986. Stable lead isotopes ratios in major French rivers and estuaries. Science of the Total Environment, 54, 61-76.

Elbaz-Poulichet, F., Morley, N.H., Beckers, J.M., Nomerange, P., 2001. Metal fluxes through the strait of gibraltar: The influence of the tinto and odiel rivers (sw spain). Marine Chemistry, 73(34), 193-213.

Evrard, O., Laceby, J.P., Huon, S., Lefèvre, I., Sengtaheuanghoung, O., Ribolzi, O., 2016. Combining multiple fallout radionuclides $(137 \mathrm{Cs}, 7 \mathrm{Be}, 210 \mathrm{Pbxs})$ to investigate temporal sediment source dynamics in tropical, ephemeral riverine systems. Journal of Soils and Sediments, 16(3), 1130-1144. 10.1007/s11368-015-1316-y.

Foucher, A., Laceby, P.J., Salvador-Blanes, S., Evrard, O., Le Gall, M., Lefèvre, I., Cerdan, O., Rajkumar, V., Desmet, M., 2015. Quantifying the dominant sources of sediment in a drained lowland agricultural catchment: The application of a thorium-based particle size correction in sediment fingerprinting. Geomorphology, 250, 271-281. 10.1016/j.geomorph.2015.09.007.

Froger, C., Ayrault, S., Quantin, C., Evrard, O., Monvoisin, G., Bordier, L., 2017. Goldschmidt Abstract, 2017-1223.

Gateuille, D., 2013. Rémanence et transfert des Hydrocarbures Aromatiques Polycycliques dans le bassin amont de la Seine - Pierre and Marie Curie University, Thesis, 304 pp.

Grosbois, C., Meybeck, M., Horowitz, A., Ficht, A., 2006. The spatial and temporal trends of $\mathrm{Cd}, \mathrm{Cu}, \mathrm{Hg}, \mathrm{Pb}$ and $\mathrm{Zn}$ in Seine River floodplain deposits (1994-2000). Science of the Total Environment, 356(1-3), 22-37. 10.1016/j.scitotenv.2005.01.049. 

polymetallic contamination patterns (1900-2009) in the Loire River sediments (France). Science of the Total Environment, 435-436, 290-305. 10.1016/j.scitotenv.2012.06.056.

Haag, I., Kern, U., Westrich, B., 2001. Erosion investigation and sediment quality measurements for a comprehensive risk assessment of contaminated aquatic sediments. Science of the Total Environment, 266(1-3), 249-257.

$\mathrm{He}, \mathrm{Q} .$, Walling, D.E., 1997. The distribution of fallout $137 \mathrm{Cs}$ and $210 \mathrm{~Pb}$ in undisturbed and cultivated soils. Applied Radiation and Isotopes, 48(5), 667-690.

Horowitz, A.J., 2008. Determining annual suspended sediment and sediment-associated trace element and nutrient fluxes. Science of the Total Environment, 400(1-3), 315-43. 10.1016/j.scitotenv.2008.04.022.

Horowitz, A.J., Meybeck, M., Idlafkih, Z., Biger, E., 1999. Variations in trace element geochemistry in the Seine River Basin based on floodplain deposits and bed sediments. Hydrological Processes, 13, 1329-1340.

Krüger, F., Meissner, R., Gröngröft, A., Grunewald, K., 2005. Flood Induced Heavy Metal and Arsenic Contamination of Elbe River Floodplain Soils. Acta hydrochimica et hydrobiologica, 33(5), 455-465. 10.1002/aheh.200400591.

Laceby, J.P., Evrard, O., Smith, H.G., Blake, W.H., Olley, J.M., Minella, J.P.G., Owens, P.N., 2017. The challenges and opportunities of addressing particle size effects in sediment source fingerprinting: A review. Earth-Science Reviews, 169, 85-103. 10.1016/j.earscirev.2017.04.009.

Le Cloarec, M.F., Bonte, P.H., Lestel, L., Lefèvre, I., Ayrault, S., 2011. Sedimentary record of metal contamination in the Seine River during the last century. Physics and Chemistry of the Earth, Parts A/B/C, 36(12), 515-529. 10.1016/j.pce.2009.02.003.

Le Gall, M., Evrard, O., Foucher, A., Laceby, J.P., Salvador-Blanes, S., Thil, F., Dapoigny, A., Lefevre, I., Cerdan, O., Ayrault, S., 2016. Quantifying sediment sources in a lowland agricultural catchment pond using $137 \mathrm{Cs}$ activities and radiogenic $87 \mathrm{Sr} / 86 \mathrm{Sr}$ ratios. Science of the Total Environment, 566-567, 968-980. 10.1016/j.scitotenv.2016.05.093.

Le Pape, P., Ayrault, S., Quantin, C., 2012. Trace element behavior and partition versus urbanization gradient in an urban river (Orge River, France). Journal of Hydrology, 472-473, 99110. 10.1016/j.jhydrol.2012.09.042.

Lepage, H., Laceby, J.P., Bonté, P., Joron, J.-L., Onda, Y., Lefèvre, I., Ayrault, S., Evrard, O., 2016. Investigating the source of radiocesium contaminated sediment in two Fukushima coastal catchments with sediment tracing techniques. Anthropocene, 13, 57-68. 10.1016/j.ancene.2016.01.004.

Marcheselli, M., Sala, L., Mauri, M., 2010. Bioaccumulation of PGEs and other trafficrelated metals in populations of the small mammal Apodemus sylvaticus. Chemosphere, 80(11), 1247-54. 10.1016/j.chemosphere.2010.06.070.

Meybeck, M., 1998. Man and river interface: multiple impacts on water and particulates chemistry illustrated in the Seine river basin. Hydrobiologia, 373/374, 1-20.

Meybeck, M., Horowitz, A.J., Grosbois, C., 2004. The geochemistry of Seine River Basin particulate matter: distribution of an integrated metal pollution index. Science of the Total Environment, 328(1-3), 219-36. 10.1016/j.scitotenv.2004.01.024.

Meybeck, M., Lestel, L., Bonte, P., Moilleron, R., Colin, J.L., Rousselot, O., Herve, D., de Ponteves, C., Grosbois, C., Thevenot, D.R., 2007. Historical perspective of heavy metals contamination $(\mathrm{Cd}, \mathrm{Cr}, \mathrm{Cu}, \mathrm{Hg}, \mathrm{Pb}, \mathrm{Zn}$ ) in the Seine River basin (France) following a DPSIR approach (1950-2005). Science of the Total Environment, 375(1-3), 204-31. 10.1016/j.scitotenv.2006.12.017.

Meybeck, M., Lestel, L., Carre, C., Bouleau, G., Garnier, J., Mouchel, J.M., 2016. Trajectories of river chemical quality issues over the Longue Duree: the Seine River (1900S-2010). Environmental Science and Pollution Research. 10.1007/s11356-016-7124-0. 
Mileusnić, M., Mapani, B.S., Kamona, A.F., Ružičić, S., Mapaure, I., Chimwamurombe, P.M., 2014. Assessment of agricultural soil contamination by potentially toxic metals dispersed from improperly disposed tailings, Kombat mine, Namibia. Journal of Geochemical Exploration, 144, 409-420. 10.1016/j.gexplo.2014.01.009.

Motha, J.A., Wallbrink, P.J., Hairsine, P.B., Grayson, R.B., 2003. Determining the sources of suspended sediment in a forested catchment in southeastern Australia. Water Resources Research, 39(3), 39-1059. 10.1029/2001wr000794.

Nriagu, J., 1989. A global assessment of natural sources of atmospheric trace metals. Nature, 338(6210), 47-49.

Nystrand, M.I., Österholm, P., Nyberg, M.E., Gustafsson, J.P., 2012. Metal speciation in rivers affected by enhanced soil erosion and acidity. Applied Geochemistry, 27(4), 906-916. 10.1016/j.apgeochem.2012.01.009.

Olley, J., Burton, J., Smolders, K., Pantus, F., Pietsch, T., 2012. The application of fallout radionuclides to determine the dominant erosion process in water supply catchments of subtropical South-east Queensland, Australia. Hydrological Processes, 27(6), 885-895. 10.1002/hyp.9422.

Ollivier, P., Radakovitch, O., Hamelin, B., 2011. Major and trace element partition and fluxes in the Rhône River. Chemical Geology, 285(1-4), 15-31. 10.1016/j.chemgeo.2011.02.011.

Owens, P.N., Batalla, R.J., Collins, A.J., Gomez, B., Hicks, D.M., Horowitz, A.J., Kondolf, G.M., Marden, M., Page, M.J., Peacock, D.H., Petticrew, E.L., Salomons, W., Trustrum, N.A., 2005. Fine-grained sediment in river systems: environmental significance and management issues. River Research and Applications, 21(7), 693-717. 10.1002/rra.878.

Pacyna, J.M., Pacyna, E.G., 2001. An assessment of global and regional emissions of trace metals to the atmosphere from anthropogenic sources worldwide. Environmental Reviews, 9(4), 269-298. 10.1139/er-9-4-269.

Priadi, C., Ayrault, S., Pacini, S., Bonte, P., 2011a. Urbanization impact on metals mobility in riverine suspended sediment: Role of metal oxides. International Journal of Environmental Science and Technology, 8(1), 1-18.

Priadi, C., Bourgeault, A., Ayrault, S., Gourlay-France, C., Tusseau-Vuillemin, M.H., Bonte, P., Mouchel, J.M., 2011b. Spatio-temporal variability of solid, total dissolved and labile metal: passive vs. discrete sampling evaluation in river metal monitoring. Journal of Environmental Monitoring, 13(5), 1470-9. 10.1039/c0em00713g.

Priadi, C., Le Pape, P., Morin, G., Ayrault, S., Maillot, F., Juillot, F., Hochreutener, R., Llorens, I., Testemale, D., Proux, O., Brown, G.E., Jr., 2012. X-ray absorption fine structure evidence for amorphous zinc sulfide as a major zinc species in suspended matter from the Seine River downstream of Paris, lle-de-France, France. Environmental Science and Technology, 46(7), 3712-20. 10.1021/es2041652.

Quevauviller, P., 1989. Impact of industrial and mine drainage wastes on the heavy metal distribution in the drainage basin and estuary of the Sado River (Portugal) Environmental Pollution, 59, 267-286.

Resongles, E., Casiot, C., Freydier, R., Dezileau, L., Viers, J., Elbaz-Poulichet, F., 2014. Persisting impact of historical mining activity to metal $(\mathrm{Pb}, \mathrm{Zn}, \mathrm{Cd}, \mathrm{Tl}, \mathrm{Hg}$ ) and metalloid $(\mathrm{As}, \mathrm{Sb})$ enrichment in sediments of the Gardon River, Southern France. Science of the Total Environment, 481, 509-21. 10.1016/j.scitotenv.2014.02.078.

Resongles, E., Casiot, C., Freydier, R., Le Gall, M., Elbaz-Poulichet, F., 2015. Variation of dissolved and particulate metal(loid) ( $\mathrm{As}, \mathrm{Cd}, \mathrm{Pb}, \mathrm{Sb}, \mathrm{Tl}, \mathrm{Zn}$ ) concentrations under varying discharge during a Mediterranean flood in a former mining watershed, the Gardon River (France). Journal of Geochemical Exploration, 158, 132-142. 10.1016/j.gexplo.2015.07.010.

Roig, N., Sierra, J., Moreno-Garrido, I., Nieto, E., Gallego, E.P., Schuhmacher, M., Blasco, J., 2016. Metal bioavailability in freshwater sediment samples and their influence on ecological 
status of river basins. Science of the Total Environment, 540, 287-96. 10.1016/j.scitotenv.2015.06.107.

Rosolen, V., De-Campos, A.B., Govone, J.S., Rocha, C., 2015. Contamination of wetland soils and floodplain sediments from agricultural activities in the Cerrado Biome (State of Minas Gerais, Brazil). Catena, 128, 203-210. 10.1016/j.catena.2015.02.007.

SIAAP, Syndicat Interdépartemental pour l'Assainissement de l'Agglomération Parisienne. Fiches d'usines, Usine d'épuration Seine Aval.

Suthar, S., Nema, A.K., Chabukdhara, M., Gupta, S.K., 2009. Assessment of metals in water and sediments of Hindon River, India: Impact of industrial and urban discharges. Journal of Hazardous Materials, 171(1-3), 1088-1095. 10.1016/j.jhazmat.2009.06.109.

Sutherland, R.a., 2000. Bed sediment-associated trace metals in an urban stream, Oahu, Hawaii. Environmental Geology, 39(6), 611-627.

Szuszkiewicz, M., Lukasik, A., Magiera, T., Mendakiewicz, M., 2016. Combination of geopedo- and technogenic magnetic and geochemical signals in soil profiles - Diversification and its interpretation: A new approach. Environmental Pollution, 214, 464-77. 10.1016/j.envpol.2016.04.044.

Tatone, L.M., Bilos, C., Skorupka, C.N., Colombo, J.C., 2016. Comparative approach for trace metal risk evaluation in settling particles from the Uruguay River, Argentina: enrichment factors, sediment quality guidelines and metal speciation. Environmental Earth Sciences, 75(7). 10.1007/s12665-016-5265-6.

Taylor, A., Blake, W.H., Smith, H.G., Mabit, L., Keith-Roach, M.J., 2013. Assumptions and challenges in the use of fallout beryllium-7 as a soil and sediment tracer in river basins. EarthScience Reviews, 126, 85-95. 10.1016/j.earscirev.2013.08.002.

Taylor, S.R., McLennan, S.M., 1995. The geochemical evolution of the continental crust. Reviews of Geophysics, 33(2), 241-265.

Thévenot, D.R., Lestel, L., Tusseau-Vuillemin, M.H., Gonzalez, J.-L., Meybeck, M., 2009. Agence de l'Eau Seine-Normandie. Les métaux dans le bassin de la Seine. Comprendre d'où proviennent et comment circulent les métaux dans un bassin versant fortement exposé aux pressions humaines.

Thévenot, D.R., Moilleron, R., Lestel, L., Gromaire, M.C., Rocher, V., Cambier, P., Bonte, P., Colin, J.L., de Ponteves, C., Meybeck, M., 2007. Critical budget of metal sources and pathways in the Seine River basin (1994-2003) for $\mathrm{Cd}, \mathrm{Cr}, \mathrm{Cu}, \mathrm{Hg}, \mathrm{Ni}, \mathrm{Pb}$ and $\mathrm{Zn}$. Science of the Total Environment, 375(1-3), 180-203. 10.1016/j.scitotenv.2006.12.008.

Tremel, A., Masson, P., Sterckeman, T., Baize, D., Mench, M., 1996. Thallium in French agrosystems - I. Thallium contents in arable soils. Environmental Pollution, 95(3), 293-302.

Turner, J.N., Brewer, P.A., Macklin, M.G., 2008. Fluvial-controlled metal and As mobilisation, dispersal and storage in the Rio Guadiamar, SW Spain and its implications for long-term contaminant fluxes to the Donana wetlands. Science of the Total Environment, 394(1), 144-61. 10.1016/j.scitotenv.2007.12.021.

Van Oldenborgh, G.J., Philip, S., Aalbers, E., Vautard, R., Otto, F., Haustein, K., Habets, F., Singh, R., Cullen, H., 2016. Rapid attribution of the May/June 2016 flood-inducing precipitation in France and Germany to climate change. Hydrology and Earth System Sciences Discussions, 1-23. 10.5194/hess-2016-308, 2016.

Véron, A., Flament, P., Bertho, M.L., Alleman, L., Flegal, R., Hamelin, B., 1999. Isotopic evidence of pollutant lead sources in northwestern France. Atmospheric Environment, 33(20), 3377-3388.

Viers, J., Dupre, B., Gaillardet, J., 2009. Chemical composition of suspended sediments in World Rivers: New insights from a new database. Science of the Total Environment, 407(2), 85368. 10.1016/j.scitotenv.2008.09.053. 
981

982

983

984

985

986

987

988

989
Xu, F., Liu, Z., Cao, Y., Qiu, L., Feng, J., Xu, F., Tian, X., 2017. Assessment of heavy metal contamination in urban river sediments in the Jiaozhou Bay catchment, Qingdao, China. Catena, 150, 9-16. 10.1016/j.catena.2016.11.004.

Zheng, Y., Luo, X., Zhang, W., Wu, X., Zhang, J., Han, F., 2016. Transport mechanisms of soil-bound mercury in the erosion process during rainfall-runoff events. Environmental Pollution, 215, 10-7. 10.1016/j.envpol.2016.04.101. 


\section{Supporting Information}

2 Table $\mathrm{S1} .{ }^{137} \mathrm{Cs}$ and ${ }^{7} \mathrm{Be}$ activities $\left(\mathrm{Bq} \mathrm{kg}^{-1}\right)$ in sediment samples.

\begin{tabular}{|c|c|c|c|c|c|c|c|c|c|}
\hline \multirow{2}{*}{$\frac{\text { Sample }}{1}$} & \multirow{2}{*}{$\begin{array}{l}\text { River } \\
\text { Seine }\end{array}$} & \multirow{2}{*}{$\begin{array}{c}\text { Localisation } \\
\text { Bray-sur-Seine }\end{array}$} & \multirow{2}{*}{$\begin{array}{l}\begin{array}{c}\text { Sampling } \\
\text { date }\end{array} \\
06 / 06 / 2016\end{array}$} & \multirow{2}{*}{$\begin{array}{c}\begin{array}{c}Y \\
\text { (Lambert) }\end{array} \\
48.41761\end{array}$} & \multirow{2}{*}{$\begin{array}{c}\begin{array}{c}\mathbf{X} \\
\text { (Lambert) }\end{array} \\
3.23822\end{array}$} & \multicolumn{2}{|c|}{${ }^{137} \mathrm{Cs} \pm 2 \sigma\left(\mathrm{Bq} \mathrm{kg}^{-1}\right)$} & \multicolumn{2}{|c|}{${ }^{7} \mathrm{Be} \pm 2 \sigma\left(\mathrm{Bq} \mathrm{kg}^{-1}\right)$} \\
\hline & & & & & & 2.4 & 0.2 & 109.3 & 6.3 \\
\hline 2 & Seine & Corbeil-Essonnes & 06/06/2016 & 48.60921 & 2.49017 & 3.3 & 0.2 & 93.7 & 5.4 \\
\hline 3 & Seine & Alfortville & 06/06/2016 & 48.80571 & 2.41055 & 2.7 & 0.1 & 136.6 & 4.9 \\
\hline 4 & Seine & Ivry-sur-Seine & 06/07/2016 & 48.79923 & 2.41441 & 5.5 & 0.4 & 144.8 & 6.2 \\
\hline 5 & Seine & Paris (Austerlitz station) & 06/06/2016 & 48.84594 & 2.36331 & 5.2 & 0.5 & 176.1 & 8.1 \\
\hline 6 & Seine & Paris (Institut du Monde Arabe) & 06/06/2016 & 48.84855 & 2.35869 & 4.9 & 0.3 & 112.7 & 4.7 \\
\hline 7 & Seine & Paris (Jussieu University) & 06/06/2016 & 48.84937 & 2.35774 & 3.8 & 0.2 & 88.8 & 5.7 \\
\hline 8 & Seine & Paris (Notre-Dame) & 06/06/2016 & 48.85051 & 2.35373 & 2.5 & 0.2 & 66.3 & 2.7 \\
\hline 9 & Seine & Paris (Orsay Museum) & 06/06/2016 & 48.86035 & 2.32744 & 4.0 & 0.2 & 131.9 & 3.5 \\
\hline 10 & Seine & Paris (Pont AlexandrellI) & 06/06/2016 & 48.86284 & 2.30478 & 4.9 & 0.2 & 135.4 & 3.4 \\
\hline 11 & Seine & Paris (Eiffel Tower) & 06/06/2016 & 48.86074 & 2.29486 & 4.1 & 0.2 & 119.6 & 2.9 \\
\hline 12 & Seine & Puteaux & 06/06/2016 & 48.87722 & 2.24565 & 3.9 & 0.1 & 94.1 & 4.8 \\
\hline 13 & Seine & Conflans St-Honorine & 06/01/2016 & 48.98772 & 2.07451 & 2.0 & 0.1 & 91.4 & 3.4 \\
\hline 14 & Seine & Vernouillet & 06/01/2016 & 48.96823 & 1.99838 & 3.6 & 0.2 & 96.7 & 5.3 \\
\hline 15 & Seine & Bouafle & 09/28/2016 & 49.21123 & 1.37151 & 2.2 & 0.2 & 10.0 & 1.3 \\
\hline 16 & Seine & Poses & 06/06/2016 & 49.30408 & 1.24755 & 3.5 & 0.2 & 227.3 & 7.3 \\
\hline 17 & Yvette & Orsay & 06/06/2016 & 48.69970 & 2.17823 & 0.5 & 0.1 & 0.0 & 10.0 \\
\hline 18 & Yvette & Orsay & 06/06/2016 & 48.69990 & 2.17799 & 0.4 & 0.1 & 12.1 & 3.4 \\
\hline 19 & Yvette & Longjumeau & 06/06/2016 & 48.68976 & 2.31176 & 0.8 & 0.1 & 61.1 & 3.7 \\
\hline 20 & Orge & Dourdan & 06/06/2016 & 48.53262 & 2.00159 & 0.6 & 0.1 & 8.5 & 0.9 \\
\hline 21 & Orge & Egly & 06/06/2016 & 48.58490 & 2.22765 & 1.2 & 0.1 & 11.0 & 1.4 \\
\hline 22 & Orge & Viry-Châtillon & 06/06/2016 & 48.67759 & 2.37896 & 0.0 & 0.5 & 24.2 & 3.0 \\
\hline 23 & Yonne & Montereau-Fault-Yonne & 06/06/2016 & 48.38178 & 2.95801 & 3.8 & 0.2 & 91.1 & 5.3 \\
\hline 24 & Loing & Moret-sur-Loing & 06/06/2016 & 48.38457 & 2.80530 & 0.6 & 0.1 & 0.0 & 9.6 \\
\hline 25 & Loing & Moret-sur-Loing & 06/06/2016 & 48.38518 & 2.80378 & 4.3 & 0.2 & 79.0 & 4.8 \\
\hline 26 & Marne & Joinville-le-Pont & 06/07/2016 & 48.81793 & 2.47020 & 2.0 & 0.2 & 64.2 & 2.4 \\
\hline 27 & Marne & Alfortville & 06/06/2016 & 48.81588 & 2.41483 & 3.5 & 0.1 & 135.3 & 4.0 \\
\hline 28 & Oise & Conflans St-Honorine & 06/06/2016 & 48.98899 & 2.07123 & 4.0 & 0.1 & 228.5 & 6.0 \\
\hline 29 & Eure & Léry-les-Damps & 06/06/2016 & 49.30398 & 1.17749 & 3.2 & 0.2 & 215.5 & 8.9 \\
\hline
\end{tabular}

3 
Table S2. Four end-members modelling results for each sediment sample.

\begin{tabular}{|c|c|c|c|c|c|c|}
\hline Sample & River & Localisation & $\begin{array}{l}\text { Recently eroded } \\
\text { subsurface } \\
(\%)\end{array}$ & $\begin{array}{l}\text { Re-suspended } \\
\text { subsurface } \\
(\%)\end{array}$ & $\begin{array}{c}\text { Recently } \\
\text { eroded surface } \\
(\%)\end{array}$ & $\begin{array}{c}\text { Re-suspended } \\
\text { surface } \\
(\%)\end{array}$ \\
\hline 1 & Seine & Bray-sur-Seine & $28 \pm 13 \%$ & $41 \pm 5 \%$ & $13 \pm 13 \%$ & $18 \pm 9 \%$ \\
\hline 2 & Seine & Corbeil-Essonnes & $17 \pm 18 \%$ & $37 \pm 8 \%$ & $19 \pm 19 \%$ & $27 \pm 13 \%$ \\
\hline 3 & Seine & Alfortville & $34 \pm 17 \%$ & $29 \pm 7 \%$ & $18 \pm 9 \%$ & $19 \pm 9 \%$ \\
\hline 4 & Seine & Ivry-sur-Seine & $12 \pm 10 \%$ & $0 \pm 5 \%$ & $47 \pm 13 \%$ & $41 \pm 14 \%$ \\
\hline 5 & Seine & Paris (Austerlitz station) & $9 \pm 9 \%$ & $0 \pm 8 \%$ & $64 \pm 13 \%$ & $27 \pm 14 \%$ \\
\hline 6 & Seine & Paris (Institut du Monde Arabe) & $1 \pm 14 \%$ & $19 \pm 6 \%$ & $47 \pm 15 \%$ & $33 \pm 10 \%$ \\
\hline 7 & Seine & Paris (Jussieu University) & $3 \pm 13 \%$ & $35 \pm 17 \%$ & $36 \pm 25 \%$ & $26 \pm 8 \%$ \\
\hline 8 & Seine & Paris (Notre-Dame) & $5 \pm 11 \%$ & $58 \pm 5 \%$ & $21 \pm 12 \%$ & $16 \pm 8 \%$ \\
\hline 9 & Seine & Paris (Orsay Museum) & $13 \pm 11 \%$ & $22 \pm 5 \%$ & $40 \pm 12 \%$ & $25 \pm 8 \%$ \\
\hline 10 & Seine & Paris (Pont AlexandrellI) & $8 \pm 30 \%$ & $12 \pm 11 \%$ & $48 \pm 34 \%$ & $32 \pm 16 \%$ \\
\hline 11 & Seine & Paris (Eiffel Tower) & $9 \pm 29 \%$ & $24 \pm 12 \%$ & $40 \pm 33 \%$ & $27 \pm 19 \%$ \\
\hline 12 & Seine & Puteaux & $3 \pm 29 \%$ & $35 \pm 12 \%$ & $36 \pm 33 \%$ & $26 \pm 19 \%$ \\
\hline 13 & Seine & Conflans St-Honorine & $16 \pm 17 \%$ & $55 \pm 7 \%$ & $19 \pm 20 \%$ & $10 \pm 12 \%$ \\
\hline 14 & Seine & Vernouillet & $8 \pm 3 \%$ & $1 \pm 38 \%$ & $66 \pm 44 \%$ & $25 \pm 15 \%$ \\
\hline 15 & Seine & Bouafle & $3 \pm 1 \%$ & $74 \pm 2 \%$ & $0 \pm 1 \%$ & $23 \pm 2 \%$ \\
\hline 16 & Seine & Poses & $39 \pm 3 \%$ & $0 \pm 1 \%$ & $51 \pm 1 \%$ & $10 \pm 3 \%$ \\
\hline 17 & Yvette & Orsay & $2 \pm 39 \%$ & $96 \pm 1 \%$ & $1 \pm 51 \%$ & $1 \pm 6 \%$ \\
\hline 18 & Yvette & Orsay & $3 \pm 3 \%$ & $96 \pm 4 \%$ & $1 \pm 1 \%$ & $0 \pm 1 \%$ \\
\hline 19 & Yvette & Longjumeau & $19 \pm 4 \%$ & $75 \pm 1 \%$ & $3 \pm 3 \%$ & $3 \pm 2 \%$ \\
\hline 20 & Orge & Dourdan & $2 \pm 2 \%$ & $96 \pm 2 \%$ & $0 \pm 2 \%$ & $2 \pm 2 \%$ \\
\hline 21 & Orge & Egly & $3 \pm 3 \%$ & $86 \pm 2 \%$ & $0 \pm 3 \%$ & $11 \pm 3 \%$ \\
\hline 22 & Orge & Viry-Châtillon & $8 \pm 1 \%$ & $92 \pm 1 \%$ & $0 \pm 1 \%$ & $0 \pm 1 \%$ \\
\hline 23 & Yonne & Montereau-Fault-Yonne & $32 \pm 2 \%$ & $24 \pm 1 \%$ & $0 \pm 1 \%$ & $44 \pm 3 \%$ \\
\hline 24 & Loing & Moret-sur-Loing & $3 \pm 2 \%$ & $95 \pm 1 \%$ & $0 \pm 1 \%$ & $2 \pm 1 \%$ \\
\hline 25 & Loing & Moret-sur-Loing & $27 \pm 2 \%$ & $22 \pm 1 \%$ & $0 \pm 1 \%$ & $51 \pm 2 \%$ \\
\hline 26 & Marne & Joinville-le-Pont & $22 \pm 1 \%$ & $57 \pm 1 \%$ & $0 \pm 1 \%$ & $21 \pm 2 \%$ \\
\hline 27 & Marne & Alfortville & $48 \pm 6 \%$ & $12 \pm 2 \%$ & $0 \pm 6 \%$ & $40 \pm 4 \%$ \\
\hline 28 & Oise & Conflans St-Honorine & $12 \pm 5 \%$ & $4 \pm 2 \%$ & $84 \pm 4 \%$ & $0 \pm 1 \%$ \\
\hline 29 & Eure & Léry-les-Damps & $24 \pm 8 \%$ & $12 \pm 2 \%$ & $64 \pm 6 \%$ & $0 \pm 1 \%$ \\
\hline
\end{tabular}

14

15

16

17

18

19

20

21

22

23 
Table S3. Trace element concentrations $\left(\mathrm{mg} \mathrm{kg}^{-1}\right)$ and lead isotope ratios $\left({ }^{207} \mathrm{~Pb} /{ }^{206} \mathrm{~Pb}\right)$ in the Seine River catchment sediment.

\begin{tabular}{|c|c|c|c|c|c|c|c|c|c|c|c|c|c|c|}
\hline Sample & River & Localisation & $\mathrm{Cr}$ & $\mathrm{Ni}$ & $\mathrm{Zn}$ & $\mathrm{Cu}$ & As & Cd & $\mathrm{Sb}$ & $\mathrm{Pb}$ & $\mathrm{Ag}$ & $\mathrm{TI}$ & Th & ${ }^{206} \mathrm{~Pb} /{ }^{207} \mathrm{~Pb}$ \\
\hline 1 & Seine & Bray-sur-Seine & 29 & 16 & 69 & 14 & 3.2 & 0.3 & 0.4 & 15 & 0.10 & 0.26 & 3.4 & $1.1847 \pm 0.0051$ \\
\hline 2 & Seine & Corbeil-Essonnes & 35 & 18 & 95 & 15 & 7.0 & 0.4 & 0.7 & 30 & 0.17 & 0.57 & 7.1 & $1.1834 \pm 0.0044$ \\
\hline 3 & Seine & Alfortville & 40 & 19 & 152 & 33 & 6.9 & 0.5 & 1.1 & 45 & 0.38 & 0.61 & 5.9 & $1.1739 \pm 0.0056$ \\
\hline 4 & Seine & Ivry-sur-Seine & 58 & 26 & 201 & 29 & 13.7 & 0.6 & 1.3 & 49 & 0.47 & 0.90 & 8.0 & $1.1716 \pm 0.0031$ \\
\hline 5 & Seine & Paris (Austerlitz station) & 60 & 27 & 222 & 33 & 12.7 & 0.6 & 1.1 & 51 & 0.54 & 0.87 & 8.0 & $1.1716 \pm 0.0017$ \\
\hline 6 & Seine & Paris (Institut du Monde Arabe) & 55 & 24 & 175 & 32 & 11.0 & 0.6 & 1.1 & 49 & 0.45 & 0.77 & 7.8 & $1.1751 \pm 0.0025$ \\
\hline 7 & Seine & Paris (Jussieu University) & 46 & 23 & 159 & 34 & 9.4 & 0.6 & 1.1 & 53 & 0.60 & 0.71 & 7.3 & $1.1716 \pm 0.0062$ \\
\hline 8 & Seine & Paris (Notre-Dame) & 36 & 15 & 158 & 28 & 7.4 & 0.5 & 1.1 & 50 & 0.36 & 0.46 & 5.7 & $1.1691 \pm 0.0022$ \\
\hline 9 & Seine & Paris (Orsay Museum) & 49 & 21 & 193 & 33 & 10.8 & 0.6 & 1.3 & 49 & 0.58 & 0.66 & 7.2 & $1.1709 \pm 0.0022$ \\
\hline 10 & Seine & Paris (Pont AlexandrellI) & 56 & 25 & 240 & 43 & 11.3 & 0.7 & 1.3 & 57 & 0.70 & 0.76 & 7.6 & $1.1710 \pm 0.0020$ \\
\hline 11 & Seine & Paris (Eiffel Tower) & 52 & 23 & 209 & 34 & 9.7 & 0.7 & 1.3 & 48 & 0.44 & 0.66 & 7.4 & $1.1714 \pm 0.0042$ \\
\hline 12 & Seine & Puteaux & 45 & 25 & 156 & 33 & 9.1 & 0.6 & 1.1 & 47 & 1.81 & 0.67 & 7.2 & $1.1737 \pm 0.0041$ \\
\hline 13 & Seine & Conflans St-Honorine & 35 & 22 & 156 & 35 & 4.8 & 1.0 & 1.4 & 64 & 3.95 & 0.36 & 4.6 & $1.1637 \pm 0.0030$ \\
\hline 14 & Seine & Vernouillet & 53 & 23 & 218 & 47 & 8.3 & 1.3 & 1.4 & 72 & 1.10 & 0.63 & 6.9 & $1.1689 \pm 0.0078$ \\
\hline 15 & Seine & Bouafle & 75 & 34 & 402 & 90 & 8.9 & 1.9 & 1.1 & 129 & 2.00 & 0.63 & 5.4 & $1.1674 \pm 0.0066$ \\
\hline 16 & Seine & Poses & 52 & 24 & 198 & 41 & 6.5 & 1.2 & 1.2 & 53 & 0.93 & 0.52 & 7.5 & $1.1726 \pm 0.0054$ \\
\hline 17 & Yvette & Orsay & 45 & 19 & 92 & 25 & 4.5 & 0.3 & 0.8 & 40 & 0.19 & 0.27 & 1.4 & $1.1744 \pm 0.0053$ \\
\hline 18 & Yvette & Orsay & 34 & 12 & 121 & 30 & 4.1 & 0.3 & 1.0 & 37 & 0.33 & 0.30 & 1.5 & $1.1672 \pm 0.0036$ \\
\hline 19 & Yvette & Longjumeau & 55 & 21 & 288 & 68 & 7.3 & 0.6 & 3.2 & 83 & 0.89 & 0.41 & 2.5 & $1.1560 \pm 0.0123$ \\
\hline 20 & Orge & Dourdan & 16 & 9 & 78 & 16 & 2.5 & 0.4 & 0.7 & 26 & 0.07 & 0.25 & 2.1 & $1.1646 \pm 0.0045$ \\
\hline 21 & Orge & Egly & 19 & 9 & 92 & 15 & 2.7 & 0.5 & 0.7 & 25 & 0.16 & 0.28 & 3.1 & $1.1618 \pm 0.0039$ \\
\hline 22 & Orge & Viry-Châtillon & 18 & 8 & 152 & 28 & 2.4 & 0.3 & 1.1 & 52 & 0.46 & 0.22 & 2.5 & $1.1583 \pm 0.0044$ \\
\hline 23 & Yonne & Montereau-Fault-Yonne & 43 & 21 & 113 & 15 & 10.8 & 0.4 & 0.6 & 35 & 0.24 & 0.89 & 8.2 & $1.1838 \pm 0.0014$ \\
\hline 24 & Loing & Moret-sur-Loing & 26 & 15 & 165 & 42 & 10.2 & 0.8 & 1.6 & 214 & 0.20 & 0.20 & 1.4 & $1.1540 \pm 0.0068$ \\
\hline 25 & Loing & Moret-sur-Loing & 44 & 23 & 300 & 67 & 11.3 & 1.1 & 2.6 & 129 & 0.63 & 0.49 & 3.9 & $1.1672 \pm 0.0076$ \\
\hline 26 & Marne & Joinville-le-Pont & 38 & 15 & 115 & 23 & 5.4 & 0.4 & 1.0 & 36 & 0.18 & 0.31 & 6.3 & $1.1728 \pm 0.0024$ \\
\hline 27 & Marne & Alfortville & 83 & 20 & 120 & 30 & 5.4 & 0.4 & 0.8 & 31 & 0.32 & 0.38 & 7.3 & $1.1768 \pm 0.0089$ \\
\hline 28 & Oise & Conflans St-Honorine & 68 & 31 & 195 & 32 & 8.0 & 0.7 & 1.3 & 41 & 0.26 & 0.48 & 7.6 & $1.1806 \pm 0.0059$ \\
\hline 29 & Eure & Léry-les-Damps & 47 & 21 & 212 & 43 & 4.8 & 1.9 & 1.8 & 156 & 0.67 & 0.35 & 7.9 & $1.1422 \pm 0.0066$ \\
\hline $\begin{array}{l}\text { ochem } \\
\text { Thé }\end{array}$ & $\begin{array}{l}\text { backg } \\
\text { lot et a }\end{array}$ & $\begin{array}{l}\text { of the Seine River catchment (from } \\
7 \text { and Le Cloarec et al., 2011) }\end{array}$ & 52 & & 76 & 14 & 5.5 & 0.3 & $<0.8$ & 26 & & & 12 & \\
\hline
\end{tabular}


Table S4. Major element concentrations $\left(\mathrm{mg} \mathrm{kg}^{-1}\right)$ in the Seine River catchment sediment.

\begin{tabular}{|c|c|c|c|c|c|c|c|c|c|}
\hline Sample & River & Localisation & $\mathrm{Na}$ & $\mathrm{Mg}$ & $\mathbf{K}$ & $\mathrm{Ca}$ & $\mathrm{Ti}$ & Mn & $\mathrm{Fe}$ \\
\hline 1 & Seine & Bray-sur-Seine & 962 & 2442 & 5174 & 247632 & 1160 & 299 & 11617 \\
\hline 2 & Seine & Corbeil-Essonnes & 1373 & 3090 & 7756 & 183693 & 1938 & 488 & 17608 \\
\hline 3 & Seine & Alfortville & 2040 & 3099 & 8512 & 155325 & 2046 & 384 & 17436 \\
\hline 4 & Seine & Ivry-sur-Seine & 1483 & 4438 & 10690 & 147500 & 2640 & 676 & 27590 \\
\hline 5 & Seine & Paris (Austerlitz station) & 1502 & 4530 & 11000 & 131100 & 2544 & 629 & 28010 \\
\hline 6 & Seine & Paris (Institut du Monde Arabe) & 1721 & 4223 & 10570 & 141200 & 2594 & 552 & 25740 \\
\hline 7 & Seine & Paris (Jussieu University) & 1904 & 3989 & 8606 & 143456 & 2155 & 506 & 20866 \\
\hline 8 & Seine & Paris (Notre-Dame) & 1712 & 3025 & 8477 & 144500 & 1758 & 406 & 16700 \\
\hline 9 & Seine & Paris (Orsay Museum) & 1816 & 3852 & 9581 & 148800 & 2337 & 519 & 22760 \\
\hline 10 & Seine & Paris (Pont AlexandrellI) & 1650 & 4403 & 10210 & 140200 & 2550 & 585 & 26750 \\
\hline 11 & Seine & Paris (Eiffel Tower) & 1899 & 4028 & 9750 & 139000 & 2377 & 543 & 23650 \\
\hline 12 & Seine & Puteaux & 1751 & 3355 & 8507 & 158586 & 2051 & 465 & 19322 \\
\hline 13 & Seine & Conflans St-Honorine & 2099 & 3024 & 6927 & 167354 & 1575 & 330 & 13238 \\
\hline 14 & Seine & Vernouillet & 2002 & 4287 & 8623 & 154057 & 1956 & 477 & 21258 \\
\hline 15 & Seine & Bouafle & 2895 & 4653 & 1890 & 142709 & 1796 & 653 & 26469 \\
\hline 16 & Seine & Poses & 2689 & 3995 & 9074 & 135074 & 2059 & 589 & 20192 \\
\hline 17 & Yvette & Orsay & 5261 & 1586 & 10884 & 14486 & 2930 & 285 & 11958 \\
\hline 18 & Yvette & Orsay & 5352 & 1829 & 11071 & 16628 & 2684 & 283 & 12700 \\
\hline 19 & Yvette & Longjumeau & 4838 & 4197 & 11742 & 35341 & 2883 & 471 & 22677 \\
\hline 20 & Orge & Dourdan & 1972 & 1501 & 6504 & 23959 & - & 189 & 7306 \\
\hline 21 & Orge & Egly & 1787 & 1378 & 8786 & 18912 & - & 251 & 7815 \\
\hline 22 & Orge & Viry-Châtillon & 1462 & 1495 & 7600 & 21099 & - & 279 & 7613 \\
\hline 23 & Yonne & Montereau-Fault-Yonne & 1454 & 3082 & 9436 & 168960 & 2015 & 475 & 18755 \\
\hline 24 & Loing & Moret-sur-Loing & 693 & 1395 & 2418 & 282077 & 704 & 248 & 23055 \\
\hline 25 & Loing & Moret-sur-Loing & 945 & 2650 & 5588,3 & 181317 & 1775 & 436 & 23097 \\
\hline 26 & Marne & Joinville-le-Pont & 2556 & 4311 & 8846 & 132300 & 2257 & 382 & 17400 \\
\hline 27 & Marne & Alfortville & 2987 & 4577 & 9864 & 104536 & 2266 & 417 & 19575 \\
\hline 28 & Oise & Conflans St-Honorine & 3109 & 5621 & 12314 & 73848 & 2561 & 1052 & 31845 \\
\hline 29 & Eure & Léry-les-Damps & 3910 & 2798 & 8957 & 65268 & 2359 & 380 & 18339 \\
\hline
\end{tabular}

28

29

30

31

32

33

34

35

36

37

38

39

40

41 
Table S5. Enrichment Factor values for each sediment sample (Th normalization).

\begin{tabular}{|c|c|c|c|c|c|c|c|c|c|c|}
\hline Sample & River & Localisation & $\mathrm{Cr}$ & $\mathrm{Ni}$ & $\mathrm{Zn}$ & $\mathrm{Cu}$ & As & Cd & $\mathrm{Sb}$ & $\mathrm{Pb}$ \\
\hline 1 & Seine & Bray-sur-Seine & 2.0 & 2.1 & 3.3 & 3.7 & 2.1 & 3.9 & 1.7 & 2.1 \\
\hline 2 & Seine & Corbeil-Essonnes & 1.2 & 1.1 & 2.2 & 1.8 & 1.7 & 2.3 & 1.5 & 2.0 \\
\hline 3 & Seine & Alfortville & 1.6 & 1.5 & 4.2 & 4.9 & 1.6 & 3.5 & 3.0 & 3.6 \\
\hline 4 & Seine & Ivry-sur-Seine & 1.7 & 1.5 & 4.1 & 3.1 & 2.0 & 2.9 & 2.5 & 2.9 \\
\hline 5 & Seine & Paris (Austerlitz station) & 1.8 & 1.5 & 4.5 & 3.6 & 1.8 & 3.1 & 2.2 & 3.0 \\
\hline 6 & Seine & Paris (Institut du Monde Arabe) & 1.7 & 1.4 & 3.6 & 3.6 & 1.7 & 3.1 & 2.3 & 3.0 \\
\hline 7 & Seine & Paris (Jussieu University) & 1.5 & 1.4 & 3.5 & 4.1 & 1.8 & 3.3 & 2.3 & 3.5 \\
\hline 8 & Seine & Paris (Notre-Dame) & 1.5 & 1.2 & 4.5 & 4.3 & 1.9 & 3.3 & 2.8 & 4.1 \\
\hline 9 & Seine & Paris (Orsay Museum) & 1.6 & 1.4 & 4.3 & 4.0 & 2.0 & 3.3 & 2.8 & 3.2 \\
\hline 10 & Seine & Paris (Pont Alexandrelli) & 1.7 & 1.5 & 5.1 & 5.0 & 1.8 & 3.6 & 2.6 & 3.5 \\
\hline 11 & Seine & Paris (Eiffel Tower) & 1.7 & 1.4 & 4.6 & 4.0 & 1.8 & 3.8 & 2.7 & 3.0 \\
\hline 12 & Seine & Puteaux & 1.5 & 1.6 & 3.5 & 4.1 & 1.8 & 3.2 & 2.3 & 3.1 \\
\hline 13 & Seine & Conflans St-Honorine & 1.8 & 2.2 & 5.5 & 6.8 & 1.6 & 8.8 & 4.6 & 6.6 \\
\hline 14 & Seine & Vernouillet & 1.8 & 1.5 & 5.1 & 6.0 & 1.6 & 7.8 & 3.1 & 5.0 \\
\hline 15 & Seine & Bouafle & 3.3 & 2.8 & 12.1 & 14.7 & 1.7 & 14.4 & 3.2 & 11.3 \\
\hline 16 & Seine & Poses & 1.7 & 1.5 & 4.3 & 4.8 & 1.4 & 6.5 & 2.4 & 3.3 \\
\hline 17 & Yvette & Orsay & 5.3 & 3.6 & 13.1 & 17.6 & 1.1 & 7.4 & 10.5 & 11.7 \\
\hline 18 & Yvette & Orsay & 7.6 & 6.3 & 10.6 & 15.5 & 1.3 & 8.1 & 8.7 & 13.4 \\
\hline 19 & Yvette & Longjumeau & 5.2 & 3.8 & 18.7 & 24.0 & 1.4 & 10.5 & 19.8 & 15.7 \\
\hline 20 & Orge & Dourdan & 1.9 & 2.0 & 6.0 & 6.7 & 1.2 & 7.1 & 5.3 & 7.2 \\
\hline 21 & Orge & Egly & 1.4 & 1.3 & 4.8 & 4.2 & 1.1 & 6.1 & 3.4 & 3.8 \\
\hline 22 & Orge & Viry-Châtillon & 1.7 & 1.4 & 9.8 & 9.7 & 1.2 & 5.7 & 6.9 & 9.9 \\
\hline 23 & Yonne & Montereau-Fault-Yonne & 1.3 & 1.2 & 2.2 & 1.6 & 2.2 & 2.2 & 1.2 & 2.0 \\
\hline 24 & Loing & Moret-sur-Loing & 4.4 & 5.0 & 19.1 & 26.5 & 6.8 & 23.8 & 17.7 & 72.4 \\
\hline 25 & Loing & Moret-sur-Loing & 2.7 & 2.7 & 12.5 & 15.0 & 2.3 & 11.8 & 10.2 & 15.6 \\
\hline 26 & Marne & Joinville-le-Pont & 1.4 & 1.1 & 2.9 & 3.2 & 1.4 & 2.5 & 2.5 & 2.7 \\
\hline 27 & Marne & Alfortville & 1.4 & 1.1 & 2.1 & 2.7 & 1.0 & 1.8 & 1.6 & 1.7 \\
\hline 28 & Oise & Conflans St-Honorine & 2.1 & 1.8 & 4.2 & 3.7 & 1.3 & 3.6 & 2.6 & 2.6 \\
\hline 29 & Eure & Léry-les-Damps & 1.4 & 1.2 & 4.3 & 4.8 & 0.9 & 10.1 & 3.4 & 9.3 \\
\hline
\end{tabular}

43

44

45

46

47

48

49

50

51

52

53 
Table S6. Enrichment Factor values for each sediment sample (Al normalization).

\begin{tabular}{|c|c|c|c|c|c|c|c|c|c|c|}
\hline Sample & River & Localisation & $\mathrm{Cr}$ & $\mathrm{Ni}$ & $\mathrm{Zn}$ & $\mathrm{Cu}$ & As & Cd & $\mathrm{Sb}$ & $\mathrm{Pb}$ \\
\hline 1 & Seine & Bray-sur-Seine & 0,99 & 1,0 & 1,6 & 1,8 & 1,0 & 1,9 & 0,8 & 1,0 \\
\hline 2 & Seine & Corbeil-Essonnes & 0,92 & 0,9 & 1,7 & 1,5 & 1,7 & 1,8 & 1,2 & 1,6 \\
\hline 3 & Seine & Alfortville & 0,95 & 0,9 & 2,5 & 3,0 & 1,6 & 2,1 & 1,8 & 2,2 \\
\hline 4 & Seine & Ivry-sur-Seine & 0,89 & 0,8 & 2,1 & 1,6 & 2,0 & 1,5 & 1,3 & 1,5 \\
\hline 5 & Seine & Paris (Austerlitz station) & 0,90 & 0,8 & 2,3 & 1,8 & 1,8 & 1,6 & 1,1 & 1,5 \\
\hline 6 & Seine & Paris (Institut du Monde Arabe) & 0,92 & 0,8 & 2,0 & 2,0 & 1,7 & 1,7 & 1,2 & 1,6 \\
\hline 7 & Seine & Paris (Jussieu University) & 0,93 & 0,9 & 2,2 & 2,6 & 1,8 & 2,1 & 1,4 & 2,2 \\
\hline 8 & Seine & Paris (Notre-Dame) & 0,98 & 0,8 & 3,0 & 2,8 & 1,9 & 2,2 & 1,9 & 2,7 \\
\hline 9 & Seine & Paris (Orsay Museum) & 0,97 & 0,8 & 2,6 & 2,4 & 2,0 & 2,0 & 1,7 & 1,9 \\
\hline 10 & Seine & Paris (Pont Alexandrelli) & 0,94 & 0,8 & 2,8 & 2,7 & 1,8 & 2,0 & 1,4 & 1,9 \\
\hline 11 & Seine & Paris (Eiffel Tower) & 1,01 & 0,8 & 2,7 & 2,4 & 1,8 & 2,3 & 1,6 & 1,8 \\
\hline 12 & Seine & Puteaux & 0,96 & 1,0 & 2,3 & 2,7 & 1,8 & 2,1 & 1,5 & 2,0 \\
\hline 13 & Seine & Conflans St-Honorine & 1,22 & 1,5 & 3,7 & 4,6 & 1,6 & 6,0 & 3,1 & 4,5 \\
\hline 14 & Seine & Vernouillet & 1,09 & 0,9 & 3,1 & 3,6 & 1,6 & 4,6 & 1,9 & 3,0 \\
\hline 15 & Seine & Bouafle & 1,48 & 1,3 & 5,4 & 6,6 & 1,7 & 6,5 & 1,5 & 5,1 \\
\hline 16 & Seine & Poses & 1,16 & 1,0 & 3,0 & 3,4 & 1,4 & 4,6 & 1,7 & 2,3 \\
\hline 17 & Yvette & Orsay & 0,92 & 0,6 & 2,3 & 3,1 & 1,1 & 1,3 & 1,8 & 2,0 \\
\hline 18 & Yvette & Orsay & 1,34 & 1,1 & 1,9 & 2,7 & 1,3 & 1,4 & 1,5 & 2,4 \\
\hline 19 & Yvette & Longjumeau & 1,11 & 0,8 & 4,0 & 5,1 & 1,4 & 2,3 & 4,2 & 3,4 \\
\hline 20 & Orge & Dourdan & 0,90 & 0,9 & 2,7 & 3,1 & 1,2 & 3,2 & 2,4 & 3,4 \\
\hline 21 & Orge & Egly & 0,80 & 0,7 & 2,8 & 2,4 & 1,1 & 3,5 & 1,9 & 6,4 \\
\hline 22 & Orge & Viry-Châtillon & 0,90 & 0,8 & 5,4 & 5,4 & 1,2 & 3,2 & 3,8 & 2,8 \\
\hline 23 & Yonne & Montereau-Fault-Yonne & 0,93 & 0,9 & 1,7 & 1,2 & 2,2 & 1,6 & 0,9 & 1,5 \\
\hline 24 & Loing & Moret-sur-Loing & 1,83 & 2,1 & 8,0 & 11,1 & 6,8 & 10,0 & 7,4 & 30,3 \\
\hline 25 & Loing & Moret-sur-Loing & 0,95 & 1,0 & 4,5 & 5,4 & 2,3 & 4,2 & 3,7 & 5,6 \\
\hline 26 & Marne & Joinville-le-Pont & 1,01 & 0,8 & 2,1 & 2,2 & 1,4 & 1,8 & 1,8 & 1,9 \\
\hline 27 & Marne & Alfortville & 0,97 & 0,8 & 1,5 & 1,9 & 1,0 & 1,3 & 1,1 & 1,2 \\
\hline 28 & Oise & Conflans St-Honorine & 1,13 & 1,0 & 2,2 & 2,0 & 1,3 & 1,9 & 1,4 & 1,4 \\
\hline 29 & Eure & Léry-les-Damps & 0,98 & 0,8 & 3,0 & 3,3 & 0,9 & 6,9 & 2,4 & 6,4 \\
\hline
\end{tabular}




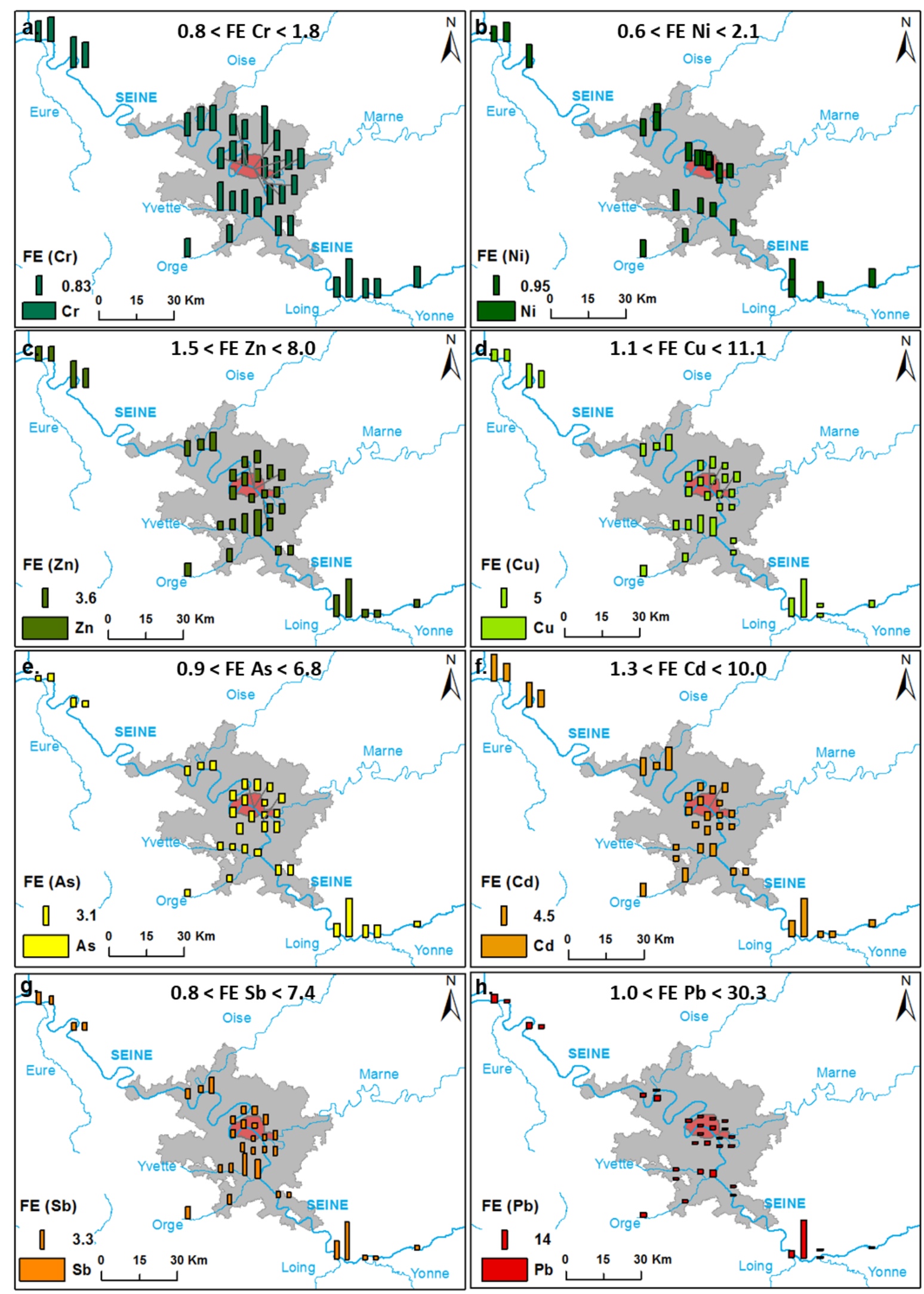

Figure S1. Enrichments Factors (EF) for $\mathrm{Cr}, \mathrm{Ni}, \mathrm{Zn}, \mathrm{Cu}, \mathrm{As}, \mathrm{Cd}, \mathrm{Sb}$ and $\mathrm{Pb}$ calculated for each sediment sample collected along the Seine River and its main tributaries. EFs were calculated after Al normalization. 
60 Table S7. Spearman correlation matrix for elemental concentration normalized to Th conentrations

\begin{tabular}{|c|c|c|c|c|c|c|c|c|c|c|c|c|c|c|c|c|c|c|}
\hline & $\mathrm{Cr}$ & $\mathrm{Ni}$ & $\mathrm{Zn}$ & $\mathrm{Cu}$ & As & $\mathrm{Cd}$ & Sb & $\mathrm{Pb}$ & $\mathrm{Ag}$ & $\mathrm{TI}$ & ${ }^{206} \mathrm{~Pb} /{ }^{207} \mathrm{~Pb}$ & $\mathrm{Na}$ & $\mathrm{Mg}$ & Al & K & $\mathrm{Ca}$ & ${ }^{137} \mathrm{Cs}$ & ${ }^{7} \mathrm{Be}$ \\
\hline $\mathrm{Cr}$ & 1 & 0.840 & 0.647 & 0.609 & 0.514 & 0.544 & 0.509 & 0.483 & 0.447 & 0.497 & 0.505 & 0.472 & 0.889 & 0.801 & 0.547 & -0.023 & -0.055 & -0.030 \\
\hline $\mathrm{Ni}$ & 0.840 & 1 & 0.703 & 0.709 & 0.584 & 0.673 & 0.588 & 0.616 & 0.622 & 0.629 & 0.552 & 0.414 & 0.763 & 0.815 & 0.496 & 0.107 & -0.053 & -0.048 \\
\hline $\mathrm{Zn}$ & 0.647 & 0.703 & 1 & 0.923 & 0.542 & 0.867 & 0.913 & 0.916 & 0.705 & 0.582 & 0.620 & 0.586 & 0.570 & 0.708 & 0.520 & -0.094 & -0.376 & -0.286 \\
\hline $\mathrm{Cu}$ & 0.609 & 0.709 & 0.923 & 1 & 0.405 & 0.888 & 0.903 & 0.954 & 0.764 & 0.507 & 0.695 & 0.685 & 0.546 & 0.605 & 0.484 & -0.026 & -0.468 & -0.250 \\
\hline As & 0.514 & 0.584 & 0.542 & 0.405 & 1 & 0.279 & 0.378 & 0.444 & 0.411 & 0.880 & 0.200 & -0.074 & 0.411 & 0.667 & 0.198 & 0.169 & 0.144 & -0.281 \\
\hline $\mathrm{Cd}$ & 0.544 & 0.673 & 0.867 & 0.888 & 0.279 & 1 & 0.875 & 0.883 & 0.671 & 0.324 & 0.578 & 0.653 & 0.481 & 0.541 & 0.358 & -0.012 & -0.372 & -0.128 \\
\hline $\mathrm{Sb}$ & 0.509 & 0.588 & 0.913 & 0.903 & 0.378 & 0.875 & 1 & 0.936 & 0.634 & 0.448 & 0.692 & 0.709 & 0.489 & 0.586 & 0.583 & -0.137 & -0.531 & -0.269 \\
\hline $\mathrm{Pb}$ & 0.483 & 0.616 & 0.916 & 0.954 & 0.444 & 0.883 & 0.936 & 1 & 0.767 & 0.528 & 0.644 & 0.638 & 0.431 & 0.565 & 0.432 & -0.038 & -0.489 & -0.310 \\
\hline $\mathrm{Ag}$ & 0.447 & 0.622 & 0.705 & 0.764 & 0.411 & 0.671 & 0.634 & 0.767 & 1 & 0.382 & 0.344 & 0.359 & 0.327 & 0.372 & 0.103 & 0.085 & -0.182 & -0.066 \\
\hline TI & 0.497 & 0.629 & 0.582 & 0.507 & 0.880 & 0.324 & 0.448 & 0.528 & 0.382 & 1 & 0.366 & 0.101 & 0.400 & 0.733 & 0.311 & 0.041 & -0.082 & -0.403 \\
\hline${ }^{206} \mathrm{~Pb} /{ }^{207} \mathrm{~Pb}$ & 0.505 & 0.552 & 0.620 & 0.695 & 0.200 & 0.578 & 0.692 & 0.644 & 0.344 & 0.366 & 1 & 0.721 & 0.593 & 0.555 & 0.706 & 0.109 & -0.568 & -0.465 \\
\hline $\mathrm{Na}$ & 0.472 & 0.414 & 0.586 & 0.685 & -0.074 & 0.653 & 0.709 & 0.638 & 0.359 & 0.101 & 0.721 & 1 & 0.544 & 0.376 & 0.612 & -0.383 & -0.813 & -0.319 \\
\hline $\mathrm{Mg}$ & 0.889 & 0.763 & 0.570 & 0.546 & 0.411 & 0.481 & 0.489 & 0.431 & 0.327 & 0.400 & 0.593 & 0.544 & 1 & 0.722 & 0.600 & 0.018 & -0.232 & -0.147 \\
\hline Al & 0.801 & 0.815 & 0.708 & 0.605 & 0.667 & 0.541 & 0.586 & 0.565 & 0.372 & 0.733 & 0.555 & 0.376 & 0.722 & 1 & 0.608 & -0.117 & -0.053 & -0.189 \\
\hline K & 0.547 & 0.496 & 0.520 & 0.484 & 0.198 & 0.358 & 0.583 & 0.432 & 0.103 & 0.311 & 0.706 & 0.612 & 0.600 & 0.608 & 1 & -0.290 & -0.404 & -0.161 \\
\hline $\mathrm{Ca}$ & -0.023 & 0.107 & -0.094 & -0.026 & 0.169 & -0.012 & -0.137 & -0.038 & 0.085 & 0.041 & 0.109 & -0.383 & 0.018 & -0.117 & -0.290 & 1 & 0.353 & 0.035 \\
\hline${ }^{137} \mathrm{Cs}$ & -0.055 & -0.053 & -0.376 & -0.468 & 0.144 & -0.372 & -0.531 & -0.489 & -0.182 & -0.082 & -0.568 & -0.813 & -0.232 & -0.053 & -0.404 & 0.353 & 1 & 0.537 \\
\hline${ }^{7} \mathrm{Be}$ & -0.030 & -0.048 & -0.286 & -0.250 & -0.281 & -0.128 & -0.269 & -0.310 & -0.066 & -0.403 & -0.465 & -0.319 & -0.147 & -0.189 & -0.161 & 0.035 & 0.537 & 1 \\
\hline
\end{tabular}




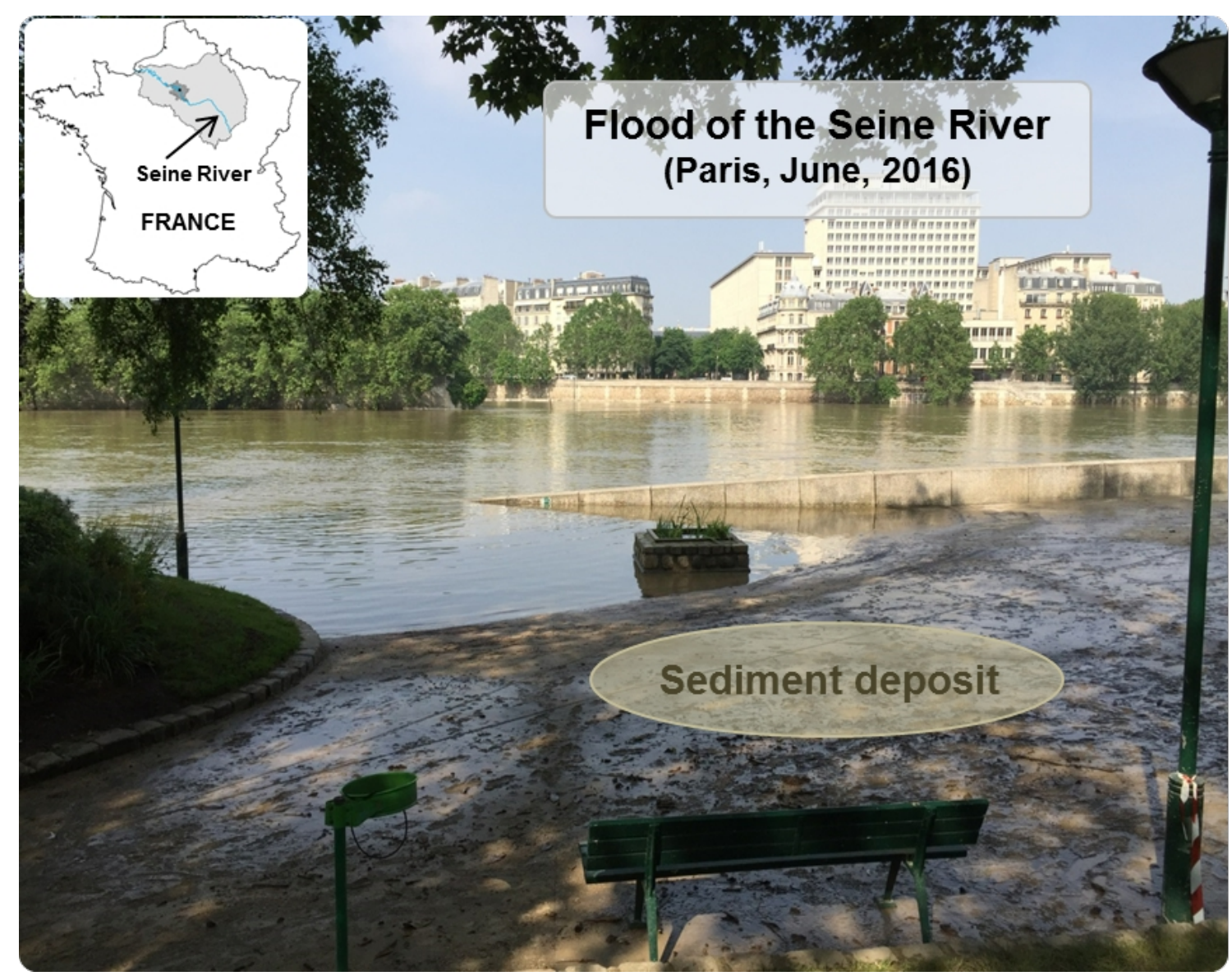

\section{Sediment deposit}

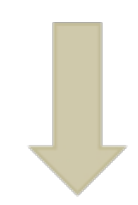

\section{Sources ?}

Radionuclide measurements $\left({ }^{137} \mathrm{Cs},{ }^{7} \mathrm{Be}\right)$ Spatial sources (surface vs subsurface) Temporal dynamics (recent vs remobilized)

\section{Metal contamination ?}

Focus on $\mathrm{Cr}, \mathrm{Ni}, \mathrm{Zn}, \mathrm{Cu}, \mathrm{As}, \mathrm{Cd}, \mathrm{Sb}, \mathrm{Pb}, \mathrm{Ag}$, TI Urban pressure $\left({ }^{206} \mathrm{~Pb} / 207 \mathrm{~Pb}\right)$ 